\title{
Late Quaternary sedimentation in Kejser Franz Joseph Fjord and the continental margin of East Greenland
}

\author{
J. EVANS ${ }^{1 *}$, J. A. DOWDESWELL ${ }^{1}$, H. GROBE 2 , F. NIESSEN ${ }^{2}$, R. STEIN ${ }^{2}$, \\ H.-W. HUBBERTEN ${ }^{3}$ \& R. J. WHITTINGTON ${ }^{4}$ \\ ${ }^{I}$ Scott Polar Research Institute, University of Cambridge, Lensfield Road, Cambridge, \\ CB2 1ER, UK \\ *Present address: Geological Division, British Antarctic Survey, \\ High Cross, Madingley Road, Cambridge, CB3 .0ET, UK (e-mail:JEV@bas.ac.uk) \\ ${ }^{2}$ Alfred Wegener Institut fur Polar-und Meeresforschung, Columbusstrasse, \\ D-27568 Bremerhaven, Germany \\ ${ }^{3}$ Alfred Wegener Institut fur Polar-und Meeresforschung, Telegrafenberg A43, \\ D-14473 Potsdam, Germany \\ ${ }^{4}$ Institute of Geography and Earth Science, University of Wales, Aberystwyth, Ceredigion, \\ $S Y 233 D B, U K$
}

\begin{abstract}
The marine sedimentary record in Kejser Franz Joseph Fjord and on the East Greenland continental margin contains a history of Late Quaternary glaciation and sedimentation. Evidence suggests that a middle-shelf moraine represents the maximum shelfward extent of the Greenland Ice Sheet during the last glacial maximum. On the upper slope, coarse-grained sediments are derived from the release of significant quantities of iceberg-rafted debris (IRD) and subsequent remobilization by subaqueous mass-flows. The middle-lower slope is characterized by hemipelagic sedimentation with lower quantities of IRD (dropstone mud and sandy mud), punctuated episodically by deposition of diamicton and graded sand/gravel facies by subaqueous debris flows and turbidity currents derived from the mass failure of upper slope sediments. The downslope decrease of IRD reflects either the action of the East Greenland Current (EGC) confining icebergs to the upper slope, or to the more ice-proximal setting of the upper slope relative to the LGM ice margin. Sediment gravity flows on the slope are likely to have fed into the East Greenland channel system, contributing to its formation in conjunction with the cascade of dense brines down the slope following sea-ice formation across the shelf.

Deglaciation commenced after $15300{ }^{14} \mathrm{C}$ years BP, as indicated by meltwater-derived light oxygen isotope ratios. An abrupt decrease in both IRD deposition and delivery of coarse-grained debris to the slope at this time supports ice recession, with icebergs confined to the shelf by the EGC. Glacier ice had abandoned the middle shelf before $13000{ }^{14} \mathrm{C}$ years BP with ice loss through iceberg calving and deposition of diamicton. Continued retreat of glacier-ice from the inner shelf and through the fjord is marked by a transition from subglacial till/bedrock in acoustic records, to ice-proximal meltwaterderived laminated mud to ice-distal bioturbated mud. Ice abandoned the inner shelf before $9100{ }^{14} \mathrm{C}$ years BP and probably stabilized in Fosters Bugt at $10000{ }^{14} \mathrm{C}$ years BP. Distinct oxygen isotope minima on the inner shelf indicate meltwater production during ice retreat. The outer fjord was free of ice before $7440{ }^{14} \mathrm{C}$ years BP. Glacier retreat through the mid-outer fjord was punctuated by topographically-controlled stillstands where iceproximal sediment was fed into fjord basins. The dominance of fine-grained, commonly laminated facies during deglaciation supports ablation-controlled, ice-mass loss.

Glacimarine sedimentation within the Holocene middle-outer fjord system is dominated by sediment gravity flow and suspension settling from meltwater plumes. Suspension sediments comprise mainly mud facies indicating significant meltwater-deposition that overwhelms debris release from icebergs in this East Greenland fjord system. The relatively widespread occurrence of fine-grained lithofacies in East Greenland fjords suggests that meltwater sedimentation can be significant in polar glacimarine environments. The icedistal continental margin is characterized by meltwater sedimentation in the inner shelf deep, iceberg scouring over shallow shelf regions, winnowing and erosion by the East Greenland Current on the middle-outer shelf, and hemipelagic sedimentation on the continental slope.
\end{abstract}

From: Dowdeswell, J. A. \& Ó CofaIgh, C. (eds) 2002. Glacier-Influenced Sedimentation on High-Latitude Continental Margins. Geological Society, London, Special Publications, 203, 149-179. 0305-8719/02/\$15.00

(c) The Geological Society of London 2002. 
Marine sediments in the fjords and on the continental margin of East Greenland record a history of sedimentation associated with Quaternary glacier-fluctuations and climate change. Investigations of marine sediments in East Greenland have been augmented by detailed studies from the Scoresby Sund fjord system (Marienfeld 1991, 1992a, b; Dowdeswell et al. 1993, 1994a, b; Ó Cofaigh et al. 2001), Kangerdlugssuaq Fjord (Syvitski et al. 1996a; Andrews et al. 1994, 1996) and the adjacent continental margin (Mienert et al. 1992; Dowdeswell et al. 1997b; Nam et al. 1995; Stein et al. 1996; Nam 1996). Correlation of the marine and terrestrial sedimentary records has provided a comprehensive reconstruction of glacial history and climatic events in East Greenland (e.g. Funder et al. 1998).

These geological investigations indicate that glacier fluctuations in East Greenland have been relatively minor during Late Quaternary glacial-interglacial periods (Funder 1989; Funder \& Hansen 1996; Funder et al. 1998) in comparison to major variations elsewhere in the Polar North Atlantic (e.g. Elverhøi et al. 1998). However, Late Quaternary sedimentation and glacial history in the more northerly fjords and continental margin of East Greenland is poorly constrained. Our understanding of the glacial history in this region has been based on only a few terrestrial geological and lake studies (Hjort 1979, 1981; Funder 1989; Wagner et al. 2000; Cremer et al. 2001). Therefore, the aim of our work is to investigate the marine sedimentary record from the northern part of East Greenland (Kejser Franz Joseph Fjord and the adjacent continental margin) in order to: (1) characterize glacimarine sedimentation along a transect from the middle-outer fjord to the continental slope; (2) to reconstruct the Late Quaternary glacial history and sedimentation for this region; and (3) to place the study within the context of sedimentation and glacier fluctuations in East Greenland and the Polar North Atlantic.

\section{Study area}

\section{Physiography and bathymetry}

Kejser Franz Joseph Fjord is located in East Greenland at $73^{\circ} \mathrm{N}$, covering an area of $2200 \mathrm{~km}^{2}$ and extending $220 \mathrm{~km}$ from fjord head to mouth (Fig. 1). Nordfjord, Geologfjord and Isfjord form tributary fjords. A prominent shallow sill characterizes the intersection of Nordfjord and Kejser Franz Joseph Fjord (Fig. 1b). The middle-outer Kejser Franz Joseph Fjord is $10-20 \mathrm{~km}$ wide and has water depths of up to $550 \mathrm{~m}$, with the outer fjord basin subdivided into three sub-basins (Fig. 1b). Fosters Bugt forms a wide embayment at the fjord mouth with maximum water depths of $340 \mathrm{~m}$. The inner continental shelf is characterized by a bathymetric deep with maximum water depths reaching $520 \mathrm{~m}$. A prominent bathymetric high is located across the inner-middle shelf with water depths of $235 \mathrm{~m}$ (Fig. 1b). The remaining shelf is 280 to $340 \mathrm{~m}$ deep and extends $110 \mathrm{~km}$ to the shelf break.

The hinterland of the middle-outer Kejser Franz Joseph Fjord and Fosters Bugt comprises a mountainous inland that slopes down to coastal lowlands, and contrasts physiographically with the steep-walled fjord interior. Glacially abandoned valleys and cirques incise the hinterland. Glacifluvial and fluvial systems fed by melting glacier-ice or snow and precipitation dissect these coastal plains (e.g. Badlanddal and Paralleldal discharging into Fosters Bugt and the outer fjord, respectively; Fig. 1c). These systems produce fjord-margin outwash deltas or alluvial fans, and surface meltwater plumes that extend to shore-distal locations. Subaerial rock-falls form talus cones along steep fjord margins.

\section{Glaciology and oceanography}

The Greenland Ice Sheet drains through the inner coastal mountain zone via Walterhausen, Adolf Hoels, Jætte, Gerrard de Geer and Nordenskjøld Gletschers that terminate at the head of Kejser Franz Joseph Fjord and its tributary fjords (Fig. 1). Walterhausen Gletscher is the largest of these glaciers, with a terminus width of $10.2 \mathrm{~km}$. The total glacier drainagebasin area exceeds $8400 \mathrm{~km}^{2}$ compared to $50000 \mathrm{~km}^{2}$ for the inner Scoresby Sund fjord system (Dowdeswell et al. 1994b).

Approximately $8 \mathrm{~km}^{3}$ of ice is calved into the fjord system each year (compared to $18 \mathrm{~km}^{3}$ in Scoresby Sund and $7 \mathrm{~km}^{3}$ in Dove Bugt), accounting for $3 \%$ of total iceberg production in Greenland (Reeh 1985). Observations indicate that icebergs in Kejser Franz Joseph Fjord are highly variable both in size and shape and their net drift is towards the fjord mouth. Shorefast sea ice prevents drift between October and June. Icebergs escaping the fjord system drift south along the continental shelf parallel to the coast within the East Greenland Current (Wadhams 1981). Multi-year sea-ice across the continental margin retreats to NE Greenland during mild summers and remains in East Greenland during moderate summers. 


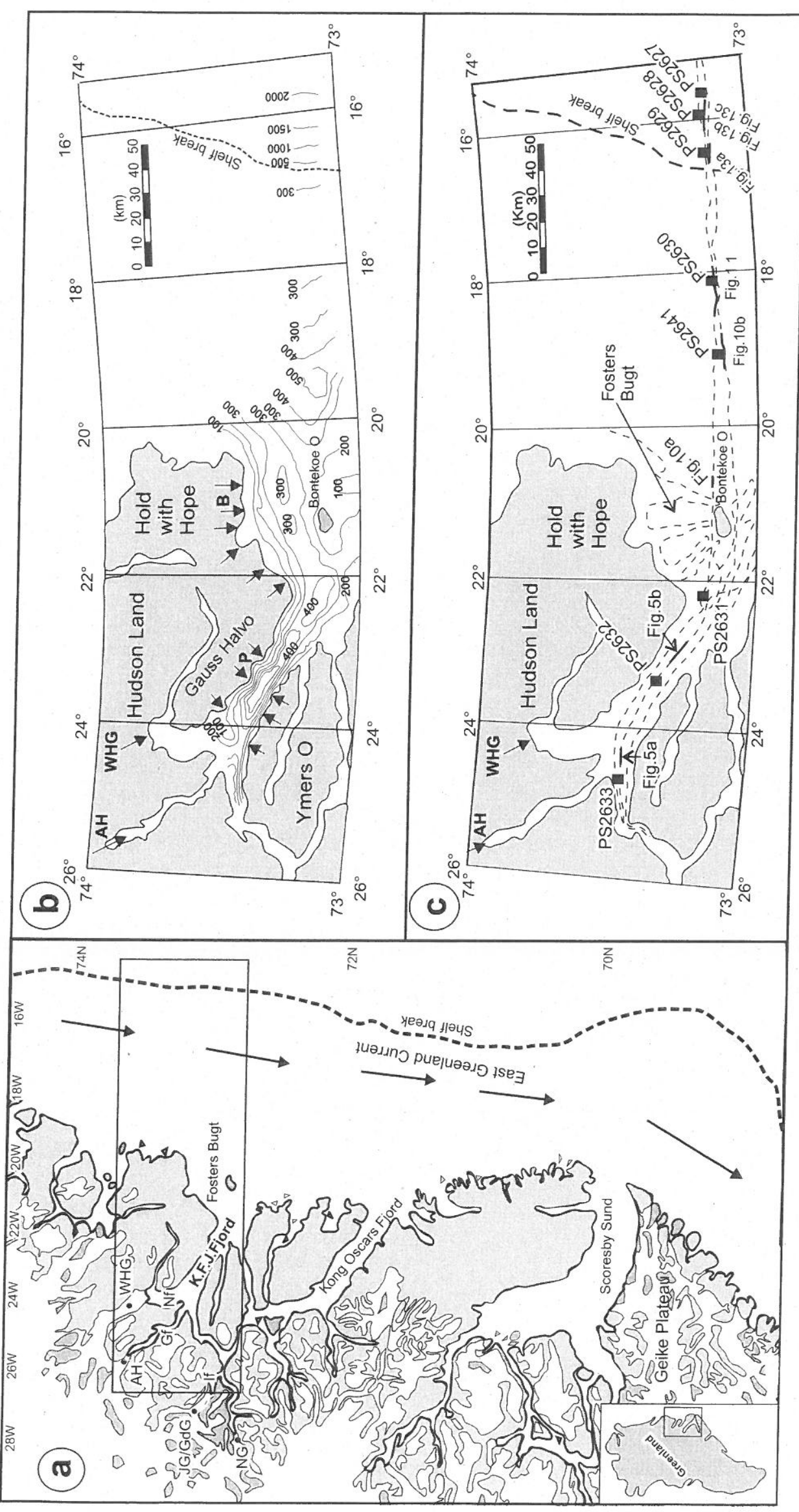

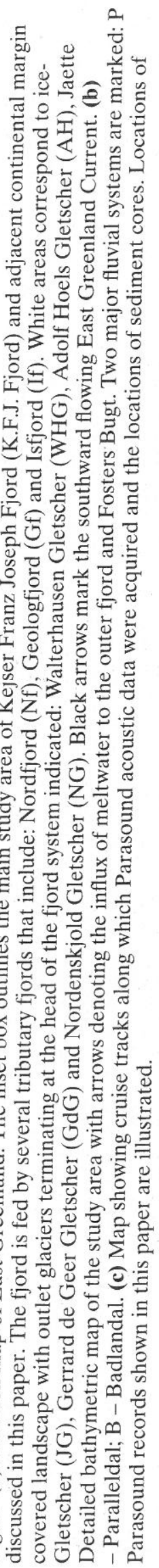


Table 1. Acoustic facies identified from Parasound records from Kejser Franz Joseph Fjord and the adjacent East Greenland continental margin

\begin{tabular}{|c|c|}
\hline Acoustic facies & Description \\
\hline $1 \mathrm{a}$ & $\begin{array}{l}\text { Acoustically stratified sediment that infills fjord basins. Smooth and continuous sea floor } \\
\text { reflector with multiple, parallel, continuous to semi-continuous sub-sea floor reflectors } \\
\text { that can pinch out laterally. Basin fill can be down-fjord in direction. }\end{array}$ \\
\hline $1 \mathrm{~b}$ & $\begin{array}{l}\text { Acoustically stratified sediment comprising a smooth continuous sea floor reflector with } \\
\text { parallel, distinct, semi-continuous to continuous reflectors that can pinch-out laterally. } \\
\text { Facies is confined to the continental shelf and slope. }\end{array}$ \\
\hline 2 & $\begin{array}{l}\text { Acoustically transparent lens-shaped sediment bodies that are up to } 20 \mathrm{~m} \text { thick and up to } \\
750 \mathrm{~m} \text { wide, although widths of several } \mathrm{km} \text { are present in fjord basins. Distinct and well- } \\
\text { defined reflectors enclose sediment lenses. Hummocky sea floor where sediment lenses } \\
\text { are located close to the sea floor on the upper slope. }\end{array}$ \\
\hline 3 & $\begin{array}{l}\text { Acoustically homogeneous sediment with a highly irregular sea floor reflector comprising } \\
\text { paired ridges and an intervening trough. Crest-trough amplitude reaches } 15 \mathrm{~m} \text { and crest- } \\
\text { to-crest width metres to tens of metres. Occurs down to water depths of } 400 \mathrm{~m} \text {. Sea floor } \\
\text { reflector is discontinuous and diffuse, and displays high intensity irregularities with sharp } \\
\text { ridge crests above } 300 \mathrm{~m} \text { water depths. Ridge crests are more rounded and sea floor } \\
\text { reflector more distinct and continuous with some areas of flat sea floor in water depths } \\
\text { between } 200 \text { and } 300 \mathrm{~m} \text {. }\end{array}$ \\
\hline 4 & $\begin{array}{l}\text { Acoustically transparent to stratified sediment (can exceed } 25 \mathrm{~m} \text { thick) with multiple, } \\
\text { parallel continuous to semi-continuous sea floor and sub-sea floor reflectors draping } \\
\text { underlying topography. Sea floor reflector can be slightly irregular, comprising small- } \\
\text { scale, low intensity irregularities separated by extensive regions of smooth sea floor. }\end{array}$ \\
\hline 5 & $\begin{array}{l}\text { Acoustically semi-transparent to crudely stratified sediment with a distinct and irregular } \\
\text { (small-scale }<5 \mathrm{~m} \text { wide) top-surface reflector. Facies thickness is highly variable but } \\
\text { generally }<10 \mathrm{~m} \text { thick. The facies is confined to the mid-outer shelf. }\end{array}$ \\
\hline 6 & $\begin{array}{l}\text { Acoustically homogeneous sediment on the upper slope. Low acoustic penetration. Sea } \\
\text { floor reflector is continuous, semi-prolonged and generally smooth and planar, but can be } \\
\text { hummocky in association with facies } 2 \text {. }\end{array}$ \\
\hline
\end{tabular}

The East Greenland Current (EGC) flows south along the continental margin (Fig. 1a). It comprises cold $\left(-1^{\circ} \mathrm{C}\right)$, polar water to a depth of $250 \mathrm{~m}$, and warm, saline return Atlantic intermediate water (RAIW) below this (Hopkins 1991). Kejser Franz Joseph Fjord comprises three water masses (Vogt et al. 1995), similar to other East Greenland fjords (Marienfeld 1991, 1992b; Syvitski et al. 1996a; Ó Cofaigh et al. 2001): (1) warm $\left(>0{ }^{\circ} \mathrm{C}\right)$, low saline $(<31$ per mil) surface water $(<25 \mathrm{~m}$ thick $)$ that extends onto the inner shelf; (2) very cold $\left(<0^{\circ} \mathrm{C}\right)$, high salinity polar waters to depths of 200-300 $\mathrm{m}$ derived from the inflow of the EGC; and (3) warm $\left(0-3{ }^{\circ} \mathrm{C}\right)$, high salinity ( $>34$ per mil) RAIW intruding into the fjord below $300 \mathrm{~m}$.

\section{Data acquisition and methods}

Geological and geophysical data were collected during the 1994 cruise of RV Polarstern to Kejser Franz Joseph Fjord and the East Greenland continental margin (Hubberten 1995; Fig.
1). The regional distribution of sediments was analysed using a Krupp-Atlas Parasound system (Grant \& Schreiber 1990). The Parasound system adopts the parametric principle where the profiling beam is generated from non-linear interaction of two primary signals of different frequencies. The resultant profiling beam produces a footprint diameter of $7 \%$ of water depth and a width of $4^{\circ}$. This enables up to $100 \mathrm{~m}$ of sediment penetration with a vertical resolution of $0.3 \mathrm{~m}$ leading to better spatial resolution than with conventional $3.5 \mathrm{kHz}$ systems (Kuhn \& Weber 1993; Dowdeswell et al. 1997a). Six acoustic facies are identified from Parasound records collected along all ship tracks (Fig. 1c; Table 1) on the basis of sea floor and sub-sea floor reflectors and associated lateral continuity, morphology and geometry (e.g. Damuth 1978).

Eight gravity cores were recovered along the fjord-shelf-slope transect (Fig. 1c; Table 2). Cores were described both visually and with Xradiographs, and lithofacies were identified using the nomenclature of Eyles et al. (1983) 
Table 2. Location, water depth and recovery length of gravity cores from Kejser Franz Joseph Fjord and the adjacent continental margin of East Greenland

\begin{tabular}{llccc}
\hline Core & Latitude & Longitude & $\begin{array}{c}\text { Water depth } \\
(\mathrm{m})\end{array}$ & $\begin{array}{l}\text { Recovery } \\
(\mathrm{m})\end{array}$ \\
\hline PS2633 & $73^{\circ} 28.8 \mathrm{~S}$ & $24^{\circ} 36.8 \mathrm{~W}$ & 283 & 5.85 \\
PS2632 & $73^{\circ} 24.4 \mathrm{~S}$ & $23^{\circ} 38.0 \mathrm{~W}$ & 505 & 2.58 \\
PS2631 & $73^{\circ} 10.7 \mathrm{~S}$ & $22^{\circ} 11.0 \mathrm{~W}$ & 430 & 7.25 \\
PS2641 & $73^{\circ} 09.3 \mathrm{~S}$ & $19^{\circ} 28.9 \mathrm{~W}$ & 469 & 3.00 \\
PS2630 & $73^{\circ} 09.5 \mathrm{~S}$ & $18^{\circ} 04.1 \mathrm{~W}$ & 287 & 2.70 \\
PS2629 & $73^{\circ} 09.5 \mathrm{~S}$ & $16^{\circ} 29.0 \mathrm{~W}$ & 850 & 2.35 \\
PS2628 & $73^{\circ} 09.8 \mathrm{~S}$ & $15^{\circ} 58.0 \mathrm{~W}$ & 1694 & 4.14 \\
\hline PS2627 & $73^{\circ} 07.4 \mathrm{~S}$ & $15^{\circ} 40.9 \mathrm{~W}$ & 2009 & \\
\hline
\end{tabular}

(Table 3). Grain size distribution was determined using wet and dry sieving and SediGraph. Mean grain size and sorting were calculated using the statistical graphical method of Folk \& Ward (1957). The number of particles coarser than $2 \mathrm{~mm}$ were point-counted using X-radiographs, and the percentage sand and gravel $>500 \mu \mathrm{m}$ determined, as an index of iceberg- rafted debris (IRD) (cf. Grobe 1987; Elverh øi et al. 1995).

The chronology of the sediments was established by radiocarbon dating of carbonate shells using the accelerator mass spectrometer (AMS) at the University of Århus. AMS radiocarbon ages were determined for specific horizons using 2000-3000 shells of the planktonic foraminifera

Table 3. Lithofacies in cores from middle-outer Kejser Franz Joseph Fjord and adjacent continental margin (after Eyles et al. 1983)

\begin{tabular}{|c|c|}
\hline Lithofacies & Description \\
\hline \multicolumn{2}{|l|}{ Diamicton } \\
\hline Dmm & $\begin{array}{l}\text { Diamicton, matrix-supported and massive. Dispersed to clustered clasts. Can form a rare } \\
\text { sandy gravel-rich lag }\end{array}$ \\
\hline $\operatorname{Dmm}(\mathrm{r})$ & $\begin{array}{l}\text { Diamicton, matrix-supported and massive with dispersed clasts to locally imbricated } \\
\text { clasts }\end{array}$ \\
\hline \multicolumn{2}{|l|}{ Gravelly sand } \\
\hline GSng & Gravelly sand, normally graded \\
\hline \multicolumn{2}{|l|}{ Sand } \\
\hline & Sand, massive \\
\hline $\operatorname{Sm}(d)$ & Sand, massive with dispersed clasts \\
\hline $\begin{array}{l}\text { Muddy sand } \\
\text { FSng }\end{array}$ & Muddy sand, normally graded \\
\hline \multicolumn{2}{|l|}{ Sandy mud } \\
\hline SFng & Sandy mud, normally graded \\
\hline SFm & Sandy mud, massive \\
\hline SFm(d) & Sandy mud, massive with dispersed clasts \\
\hline $\mathrm{SFb}(\mathrm{d})$ & Sandy mud, bioturbated with dispersed clasts \\
\hline $\operatorname{SFc}(\mathrm{m}-1)$ & $\begin{array}{l}\text { Sandy mud, rhythmic couplets comprising sand/silt rich and clay rich units with a massive } \\
\text { to planar parallel to cross-laminated structure, water escape structures }\end{array}$ \\
\hline \multicolumn{2}{|l|}{ Mud } \\
\hline Fm & Mud, massive \\
\hline $\mathrm{Fm}(\mathrm{d})$ & Mud, massive with dispersed clasts \\
\hline $\mathrm{Fm}(\mathrm{d}-\mathrm{sl})$ & Mud, massive with dispersed clasts and lenses of poorly-sorted sand \\
\hline $\mathrm{Fb}$ & Mud, bioturbated \\
\hline $\mathrm{Fb}(\mathrm{d})$ & Mud, bioturbated with dispersed clasts \\
\hline Fl & Mud, laminated with dispersed clasts \\
\hline $\mathrm{Fl}(\mathrm{d})$ & Mud, laminated with dispersed to layered clasts \\
\hline
\end{tabular}


Table 4. Radiocarbon dates for cores PS2631, PS2641, PS2630, PS2629, PS2628 and PS2627. Ages are shown in uncorrected and corrected form. The corrected ages assume a reservoir age of 550 years in East Greenland. Ages were determined on planktonic forminifera (N. pachyderma), gastropoda (Buccinum hydrophanum) and bivalvia (Thyasira gouldi, Bathyarca glacialis or Portlandia fraterna) species

\begin{tabular}{lclcc}
\hline Core & $\begin{array}{l}\text { Core Depth } \\
(\mathrm{cm})\end{array}$ & Species & $\begin{array}{l}\text { Uncorrected age } \\
14\end{array}$ & $\begin{array}{c}\text { Corrected age } \\
{ }^{14} \text { C years BP }\end{array}$ \\
\hline PS2631 & 99 & Buccinum hydrophanum & $1695+/-55$ & $1145+/-55$ \\
PS2641 & 390 & Thyasira gouldi & $7990+/-210$ & $7440+/-210$ \\
& 375 & Bathyarca glacialis & $6980+/-130$ & $6430+/-130$ \\
& 413 & Bathyarca glacialis & $7600+/-70$ & $7050+/-70$ \\
& 535 & Bathyarca glacialis & $8700+/-75$ & $8150+/-75$ \\
& 554 & Bathyarca glacialis & $9130+/-80$ & $8580+/-80$ \\
PS2630 & 565 & Portlandia fraterna & $9280+/-80$ & $8730+/-80$ \\
PS2629 & 585 & Portlandia fraterna & $9560+/-120$ & $9010+/-120$ \\
& 180 & N. pachyderma & $13560+/-130$ & $13010+/-130$ \\
PS2628 & 70 & N. pachyderma & $17510+/-160$ & $16960+/-160$ \\
& 130 & N. pachyderma & $19500+/-210$ & $18950+/-210$ \\
PS2627 & 30 & N. pachyderma & $13570+/-120$ & $13020+/-120$ \\
& 150 & N. pachyderma & $15910+/-160$ & $15360+/-160$ \\
& 210 & N. Pachyderma & $19390+/-190$ & $18840+/-190$ \\
& 20 & N. pachyderma & $9300+/-100$ & $8750+/-100$ \\
& 220 & N.pachyderma & $15880+/-120$ & $15330+/-120$ \\
& 270 & N. pachyderma & $19040+/-230$ & $18490+/-230$ \\
& 330 & N. pachyderma & $26350+/-380$ & $25800+/-380$ \\
\hline
\end{tabular}

Neogloboquadrina pachyderma $\sin$, obtained from the 125-250 $\mu \mathrm{m}$ sand fraction in PS2641, PS2630, PS2629, PS2628 and PS2627, and gastropoda and bivalvia shells in PS2631 and PS2641 (Table 4). The ocean reservoir effect for East Greenland is 550 years (Hjort 1973) and is subtracted from the raw age to obtain the reservoir corrected radiocarbon age $\left({ }^{14} \mathrm{C}\right.$ years $\left.\mathrm{BP}\right)$. There were no ash layers within the cores to corroborate radiocarbon ages independently.

\section{Chronology}

\section{Radiocarbon ages and sediment flux}

Radiocarbon ages are presented in uncorrected and marine reservoir corrected form in Table 4. Ages indicate that core sediments extend back to the Late Weichselian glaciation. An age of $10000{ }^{14} \mathrm{C}$ years BP is estimated for the surface of PS2630, as this is the last time that significant quantities of icebergs influenced the shelf to produce diamicton (see below). This interpretation is supported by an absence of Holocene diamicton on the inner shelf and in the fjords of E/NE Greenland (Stein et al. 1993; Nam 1996). An age of $13000{ }^{14} \mathrm{C}$ years BP is assumed for the top of the sand-mud couplet facies in PS2627 as this correlates with an identical, stratigraphic position in PS2628 that is dated to this time.

Radiocarbon ages allow calculation of linear sedimentation rates $\left(\mathrm{cm} \mathrm{ka}^{-1}\right)$ and bulk accumulation rates $\left(\mathrm{g} \mathrm{cm}^{-2} \mathrm{ka}^{-1}\right)$ for the cores (Fig. 2). Sediment flux decreases eastward, from a point depending on the position of the ice margin through time. Sediment delivery is generally greatest on the continental margin under full Late Weichselian glacial and deglacial conditions in response to the Greenland Ice Sheet being located on the continental shelf. Sediment flux during the Late Weichselian glaciation is $30 \mathrm{~cm} \mathrm{ka}^{-1}$ and 29 to $65 \mathrm{~g} \mathrm{~cm}^{-2} \mathrm{ka}^{-1}$ on the upper slope decreasing to $16 \mathrm{~cm} \mathrm{ka}^{-1}$ and 16-24 $\mathrm{g} \mathrm{cm}^{-2} \mathrm{ka}^{-1}$ on the mid-lower slope (Fig. 2). Sedimentation rates of $51-79 \mathrm{~cm} \mathrm{ka}^{-1}$ and $47-98 \mathrm{~g} \mathrm{~cm}^{-2} \mathrm{ka}^{-1}$ are reached between 13000 and $15300{ }^{14} \mathrm{C}$ years BP on the mid-lower slope, decreasing to $<4 \mathrm{~cm} \mathrm{ka}^{-1}$ and $<3 \mathrm{~g} \mathrm{~cm}^{-2} \mathrm{ka}^{-1}$ after $13020{ }^{14} \mathrm{C}$ years BP (Fig. 2). Holocene sediment flux is highest in the fjord and on the inner shelf (up to $111 \mathrm{~cm} \mathrm{ka}^{-1}$ and $117 \mathrm{~g} \mathrm{~cm}^{-2} \mathrm{ka}^{-1}$ ) reflecting greater proximity to the ice margin during and after retreat to its present day position (Fig. 2).

\section{Stable isotope stratigraphy}

The stable isotope stratigraphy of three cores (PS2627, PS2630 and PS2641) is presented in Figure 3. Isotope stage 2 (LGM) in PS2627 is characterized by heavy $\delta^{18} \mathrm{O}$ isotopes (>4\%o), and isotope stage 1 by lighter $\delta^{18} \mathrm{O}$ values $(<3.5 \%$ ) (Fig. 3). Intense bioturbation of 
a
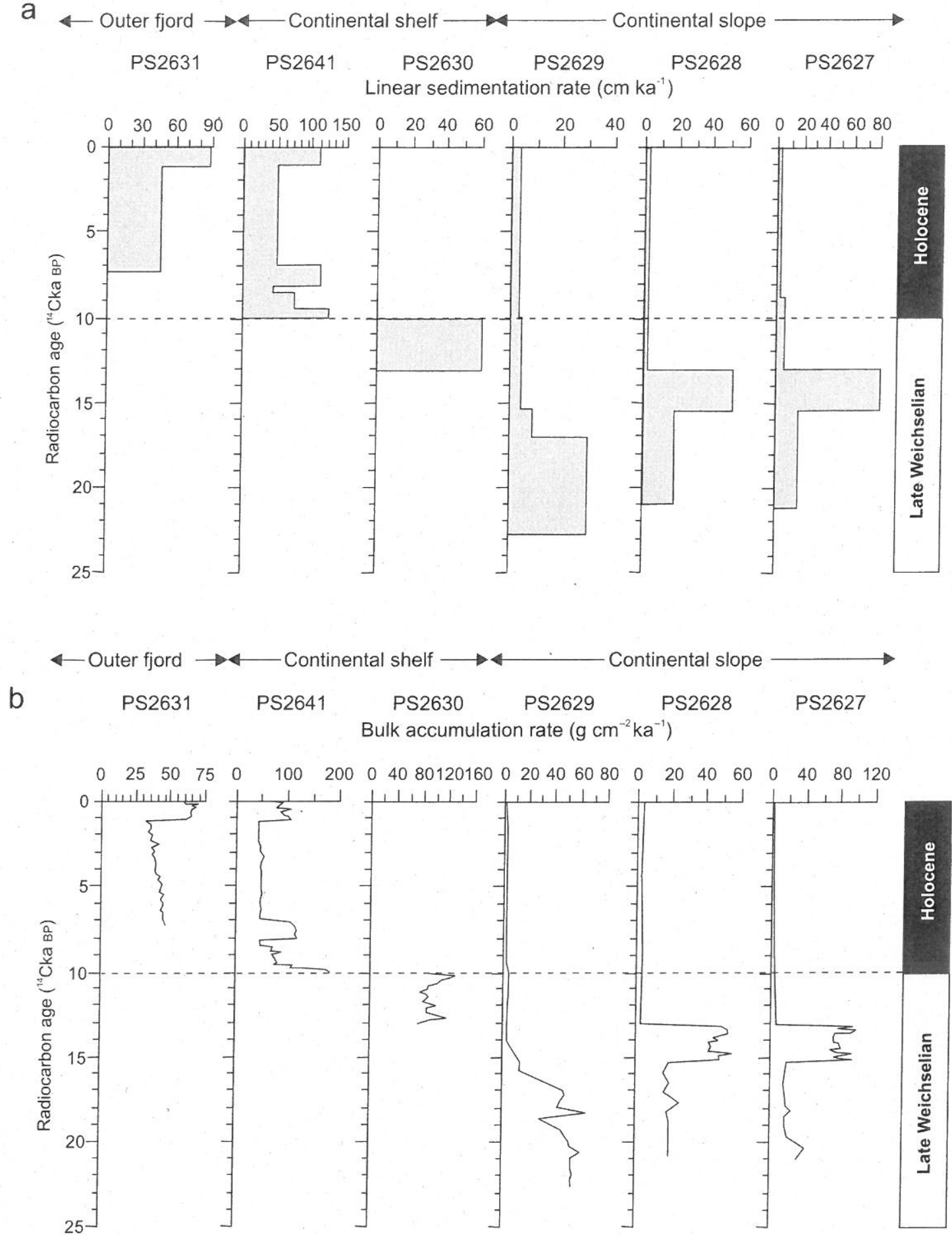

Fig. 2. (a) Sedimentation and (b) accumulation rates for cores PS2631, PS2641, PS2630, PS2629, PS2628 and PS2627, outer Kejser Franz Joseph Fjord and adjacent continental margin.

Holocene mud in PS2641 (see below) has smoothed any short-term isotopic variations that may have been present. A distinct shift of $1.67 \%$ in $\delta^{18} \mathrm{O}$ in PS2627 occurs at the Stage $2 / 1$ transition between 13020 and 15300
${ }^{14} \mathrm{C}$ years BP (Fig. 3). Similarly, $\delta^{18} \mathrm{O}$ minima (as low as $0.91 \%$ ) characterize the base of PS2641 (pre-dating $9010{ }^{14} \mathrm{C}$ years $\mathrm{BP}$ ), corresponding to meltwater-derived laminated mud (Fig. 3). PS2630 is characterized by light $\delta^{18} \mathrm{O}$ values. 

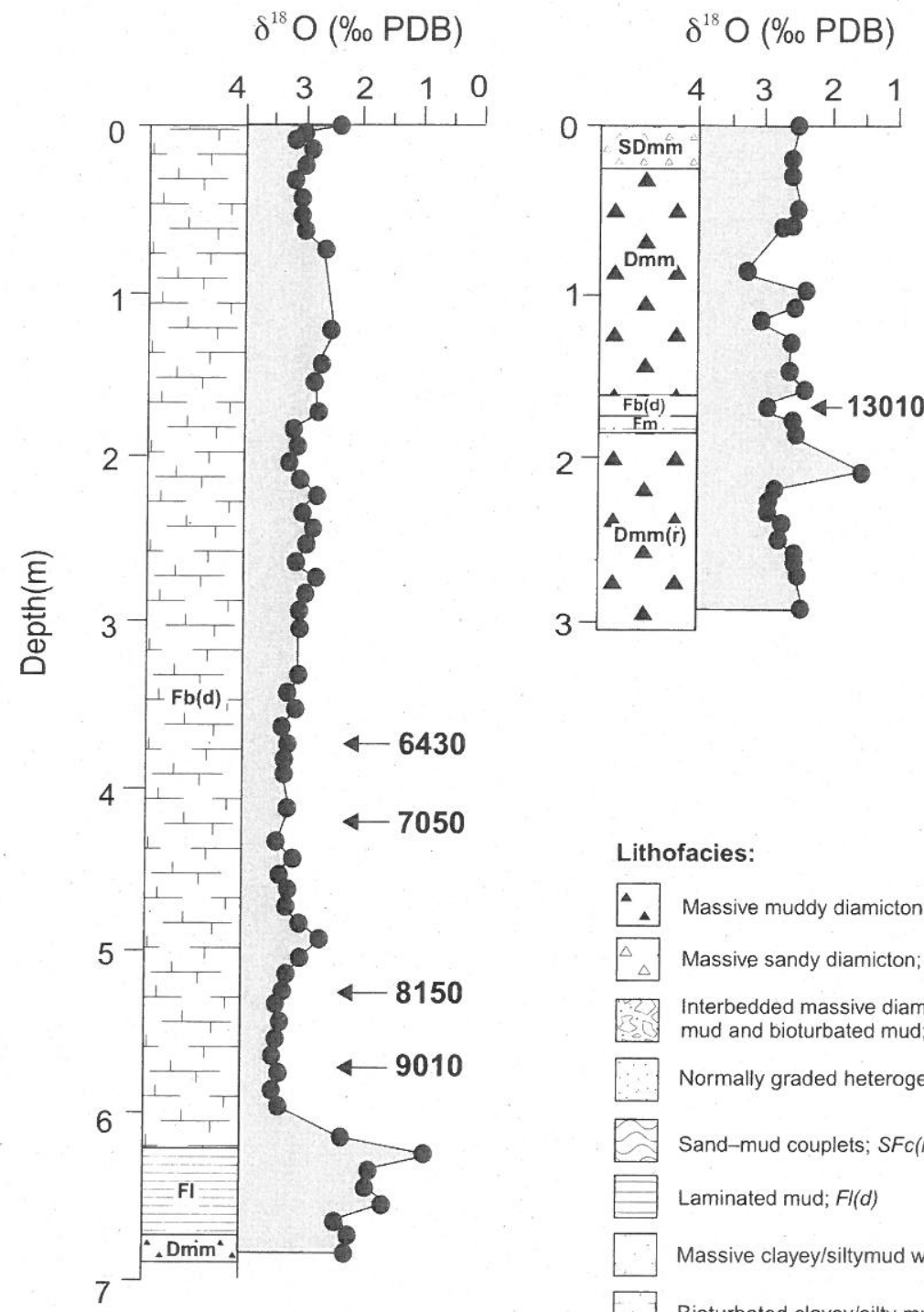

$\delta^{18} \mathrm{O}(\% \mathrm{PDB})$

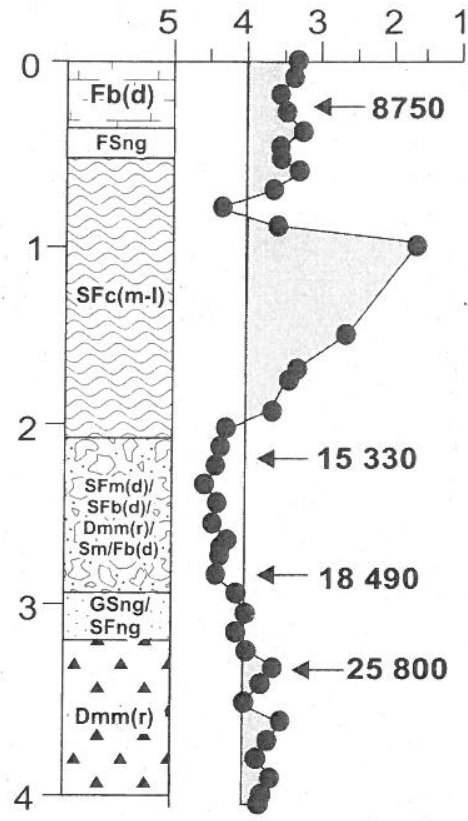

Lithofacies:

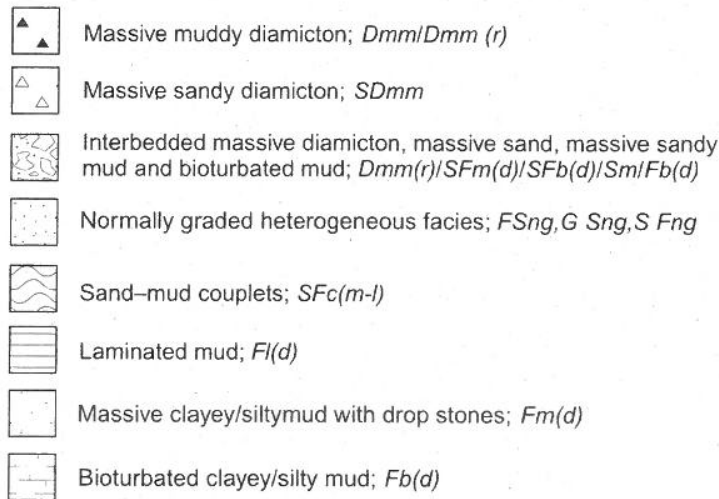

Fig. 3. Stable oxygen isotope records and corresponding lithological log of cores PS2641, PS2630 and PS2627 from the East Greenland continental margin. Core locations are shown in Figure 1c. AMS radiocarbon dates $\left({ }^{14} \mathrm{C}\right.$ years $\left.\mathrm{BP}\right)$ obtained from all cores are marked.

The distinct shift in $\delta^{18} \mathrm{O}$ values between Stage 2 and the $\delta^{18} \mathrm{O}$ minima exceed the 1.1-1.3\% associated with the glacial-interglacial icevolume effect (e.g. Chappell \& Shackleton 1986; Shackleton 1987). The excess shift in $\delta^{18} \mathrm{O}$ is unlikely to be a result of temperature change because the East Greenland Current is at present $-1{ }^{\circ} \mathrm{C}$, and additional cooling is unlikely during glacial periods. Instead, the $\delta^{18} \mathrm{O}$ minima are attributed to a decrease in surface water salinity associated with a major pulse of isotopically light meltwater during the last deglaciation (cf. Jones \& Keigwin 1988; Sarnthein et al. 1992; Stein et al. 1994 a\& b; Elverhøi et al. 1995; Nam et al. 1995; Hald et al. 1996). This meltwater event influenced the slope between 15300 and $13020{ }^{14} \mathrm{C}$ years BP, the shelf after 13020 ${ }^{14} \mathrm{C}$ years BP and terminated on the inner shelf before $9010{ }^{14} \mathrm{C}$ years BP. The meltwater signal in PS2627 corresponds to a sequence of thinly interbedded turbidites and hemipelagic muds (see below), but the signal is in-sequence (i.e. between Stages 2 and 1) and its timing is consistent with meltwater production in 

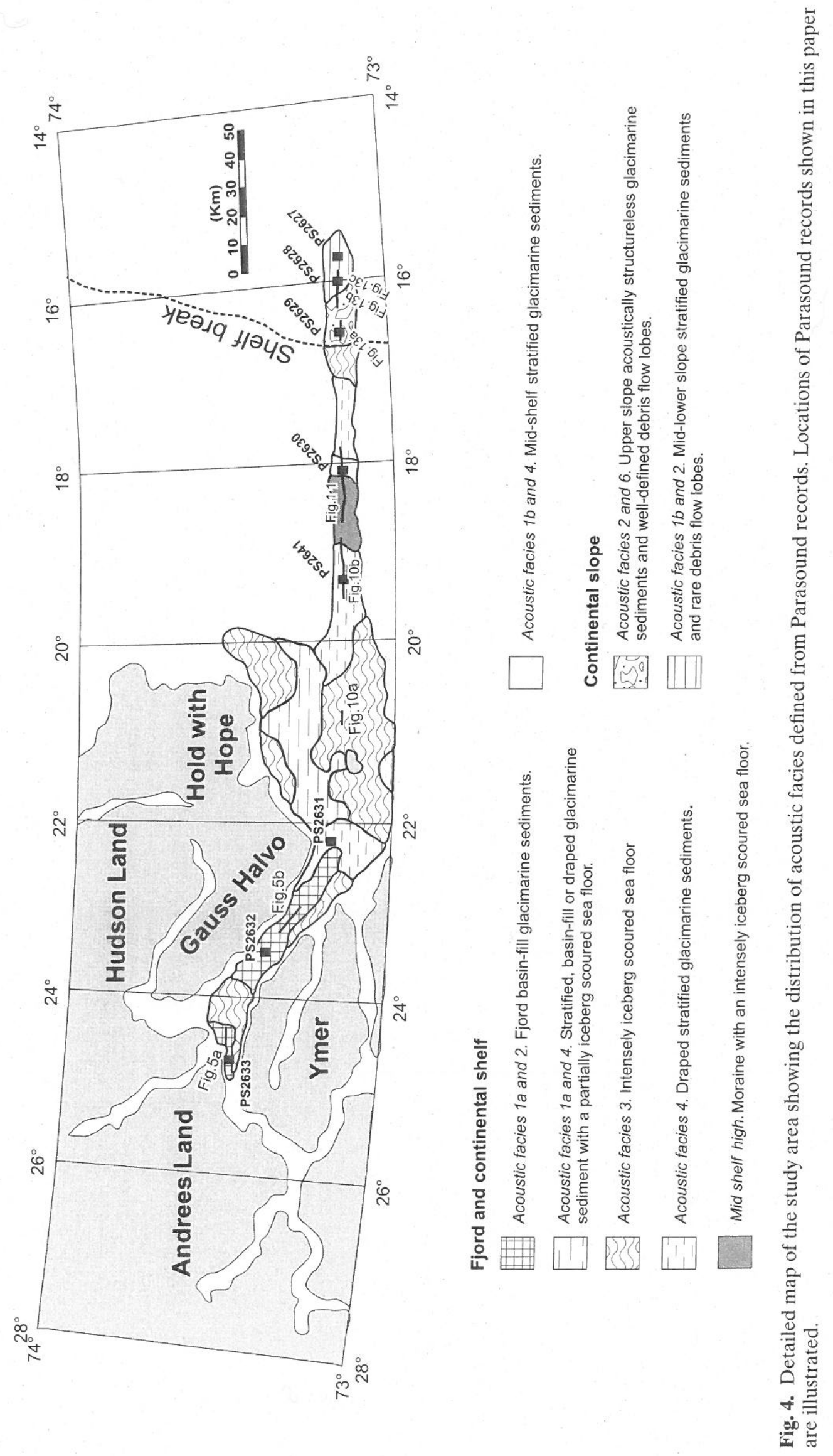


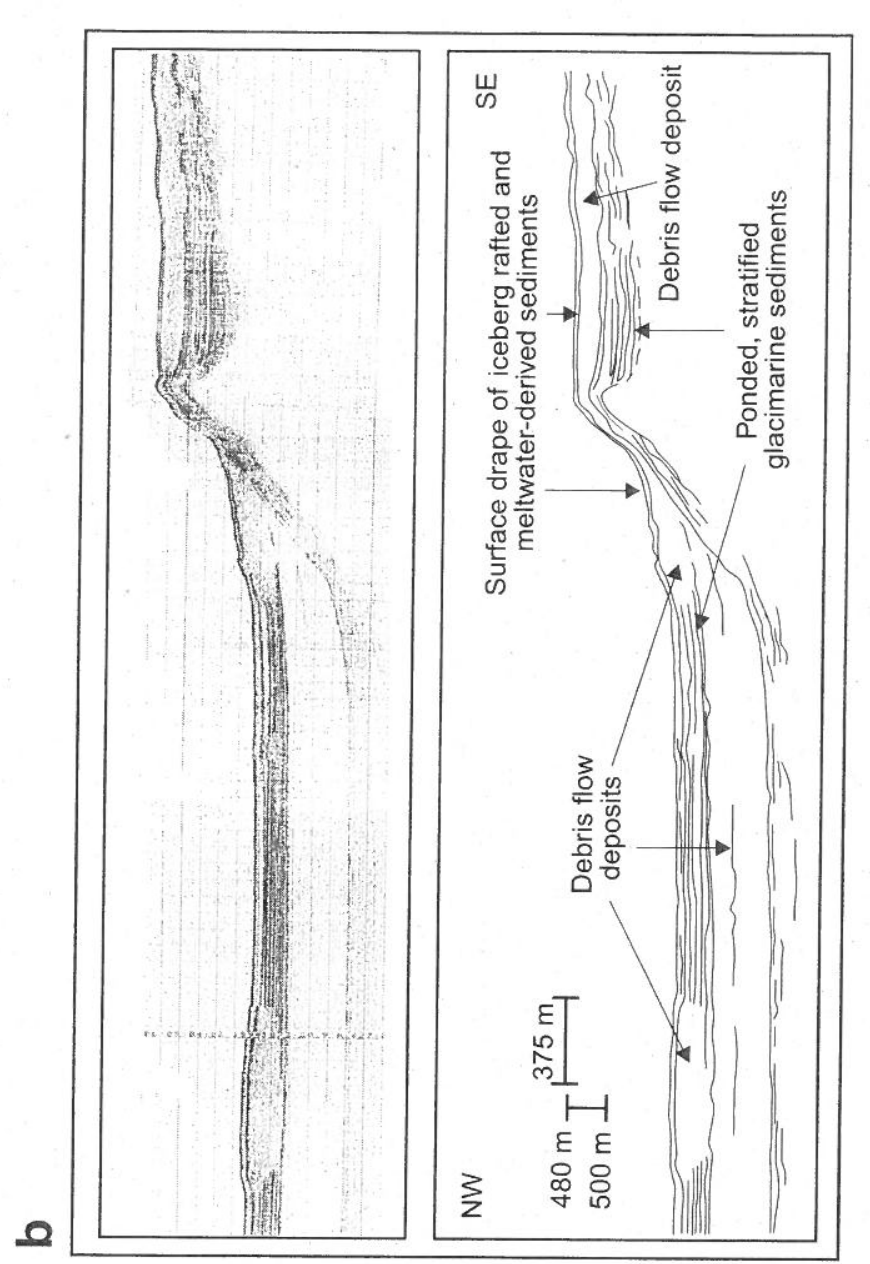

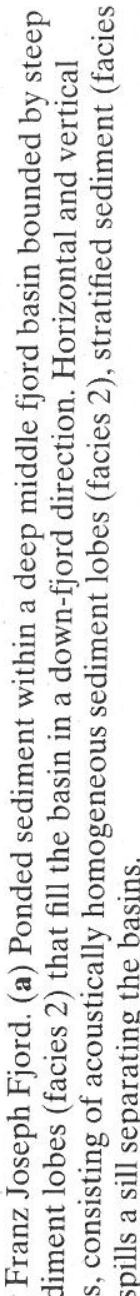

比

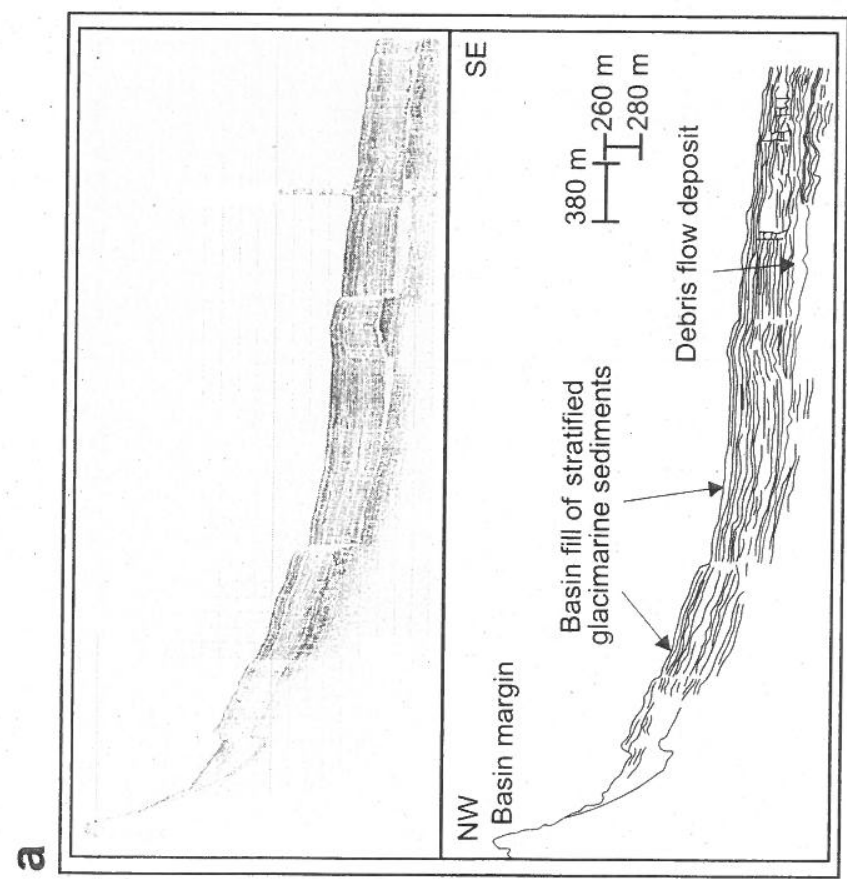

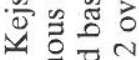

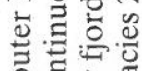

유며

号哥焉

물

毛画手

उथ

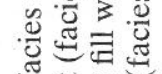

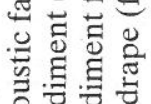

过总

记

氜

进

可高

을 吾吉

的芯芯芯

ํํㄹ을 정 


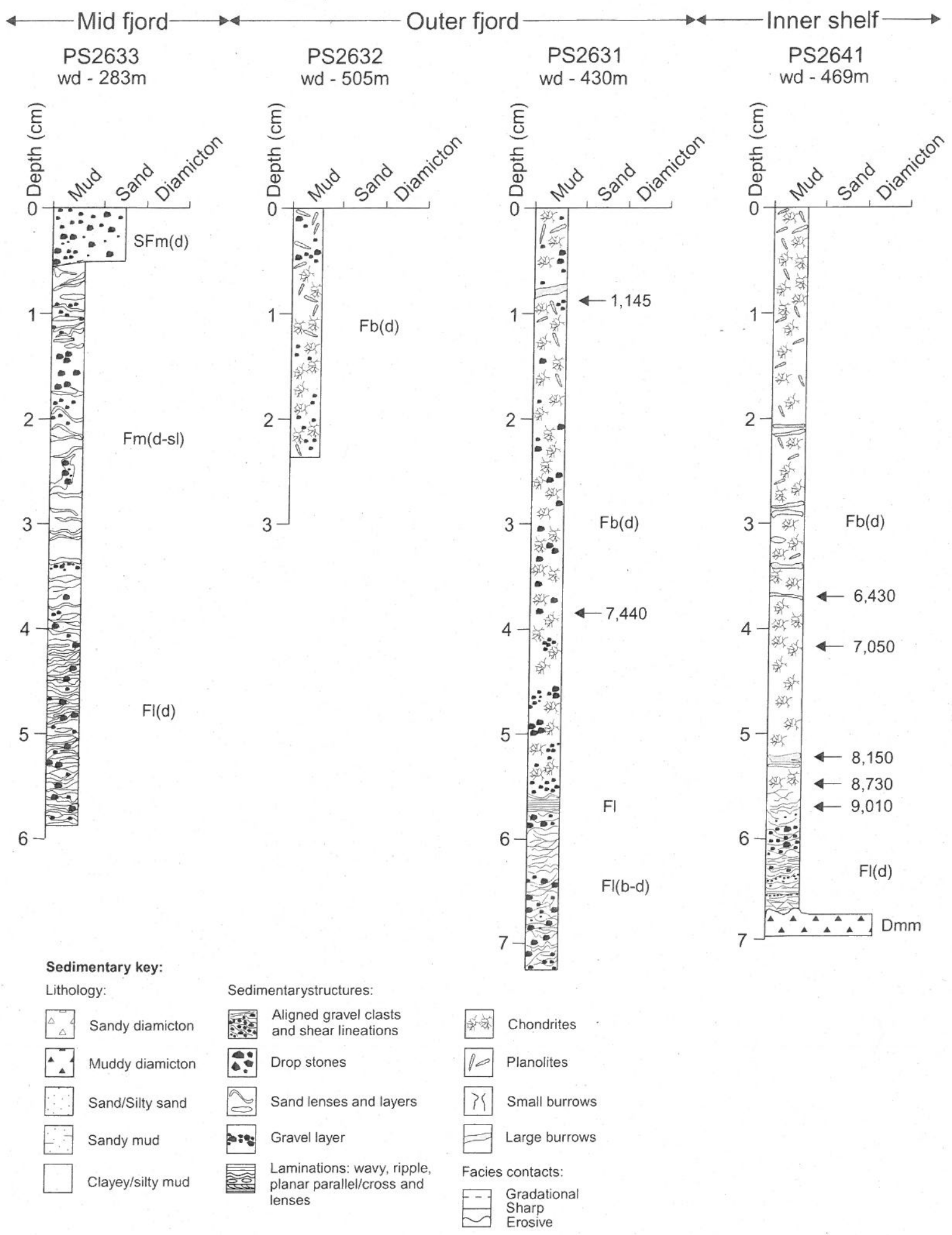

Fig. 6. Sedimentological logs of cores PS2633, PS2632, PS2631 and PS2641, middle-outer Kejser Franz Joseph Fjord and inner continental shelf. Core locations are shown in Figure 1c. AMS radiocarbon dates $\left({ }^{14} \mathrm{C}\right.$ years BP) obtained from PS2631 and PS2641 are marked. Explanation of lithofacies codes is given in Table 3. 
high-latitude regions. Therefore, it is likely that the reworking of foram shells by turbidity currents is minimal and immediately succeeds primary deposition.

\section{Kejser Franz Joseph Fjord and Fosters Bugt}

\section{Sediment thickness and acoustic facies distribution}

The mid-fjord basin comprises well-stratified sediment (facies 1a) interbedded with lensshaped sediment bodies (facies 2) that fill the basin in a down-fjord direction (Figs 4 \& 5a). Marginal fjord regions are draped by stratified sediment (facies 4). A prominent sill separating the mid- and outer fjord comprises a thin sediment cover with an irregular sea floor (facies 3 ).

The innermost sub-basin of the outer fjord comprises a sequence ( $>60 \mathrm{~m}$ thick) of stacked sediment lenses (facies 2 ) extending the length of the basin (several kilometres) overlain by well-stratified sediment (facies 1a) with isolated lenses of acoustically transparent sediment ( $<750 \mathrm{~m}$ wide, less than $20 \mathrm{~m}$ thick; facies 2 ) (Figs 4 \& 5b). In the intermediate sub-basin

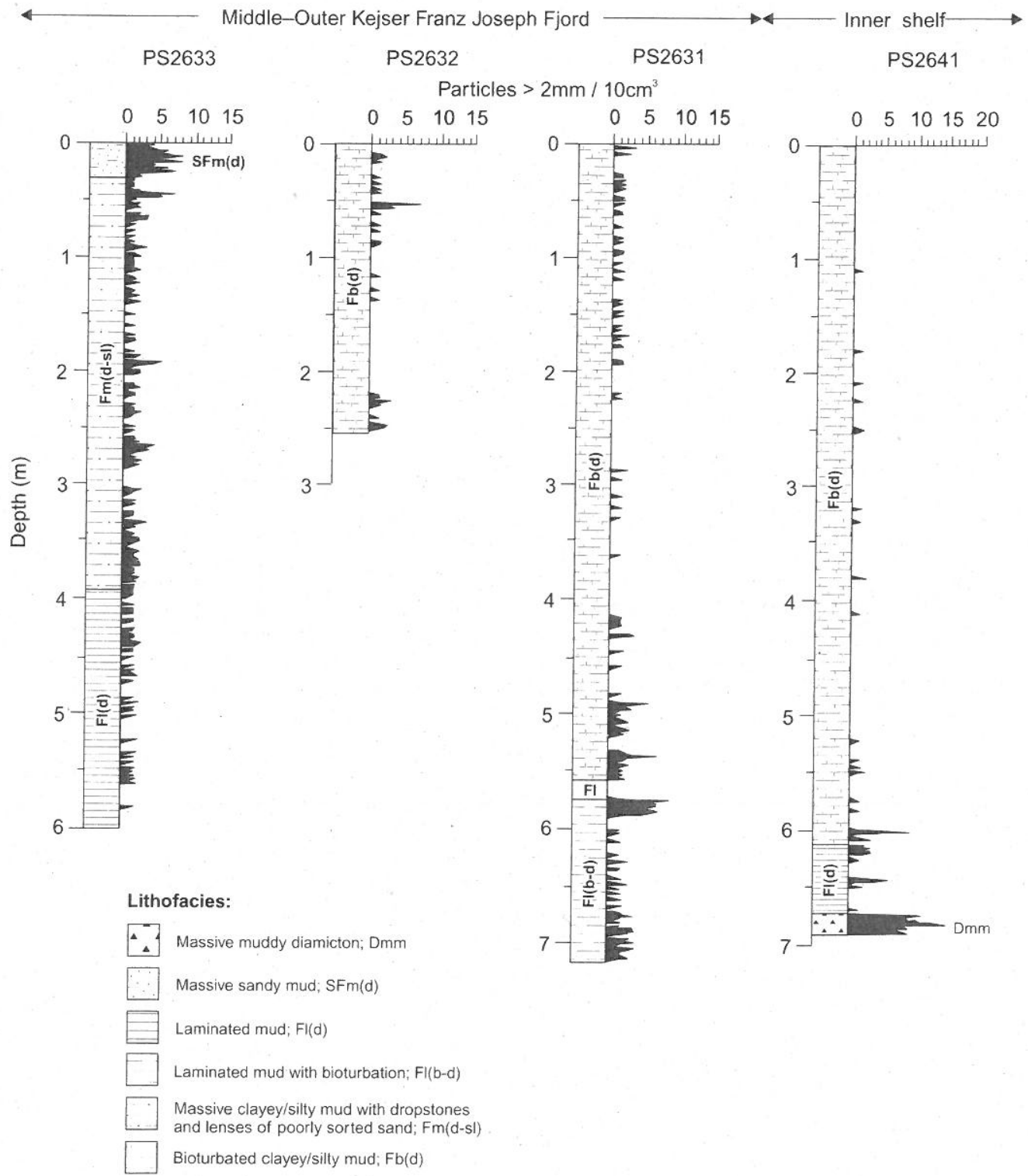

Fig. 7. Coarse-particle counts (particles $>0.2 \mathrm{~cm} / 10 \mathrm{~cm}^{3}$ ) from cores PS2633, PS2632, PS2631 and PS2641. Core locations are shown in Figure 1c. 
a. PS2631

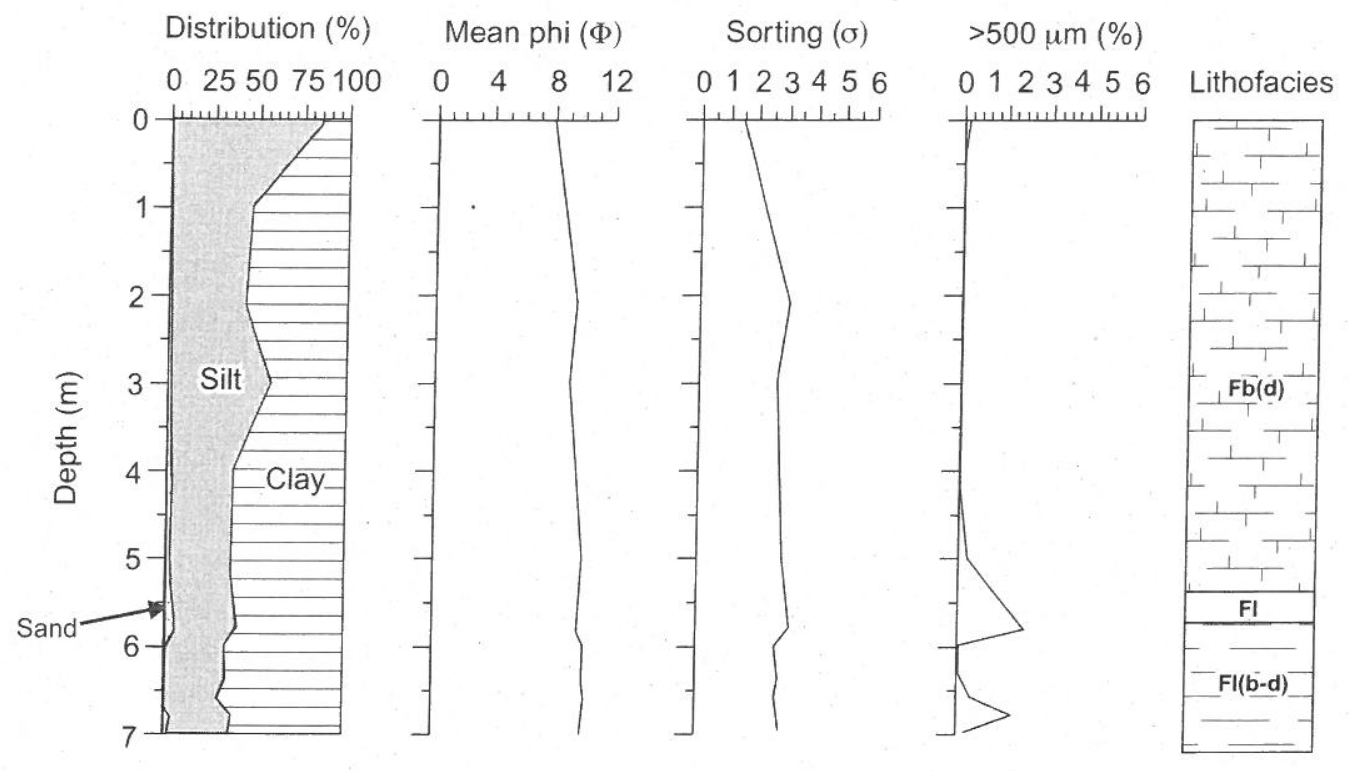

b. PS2641

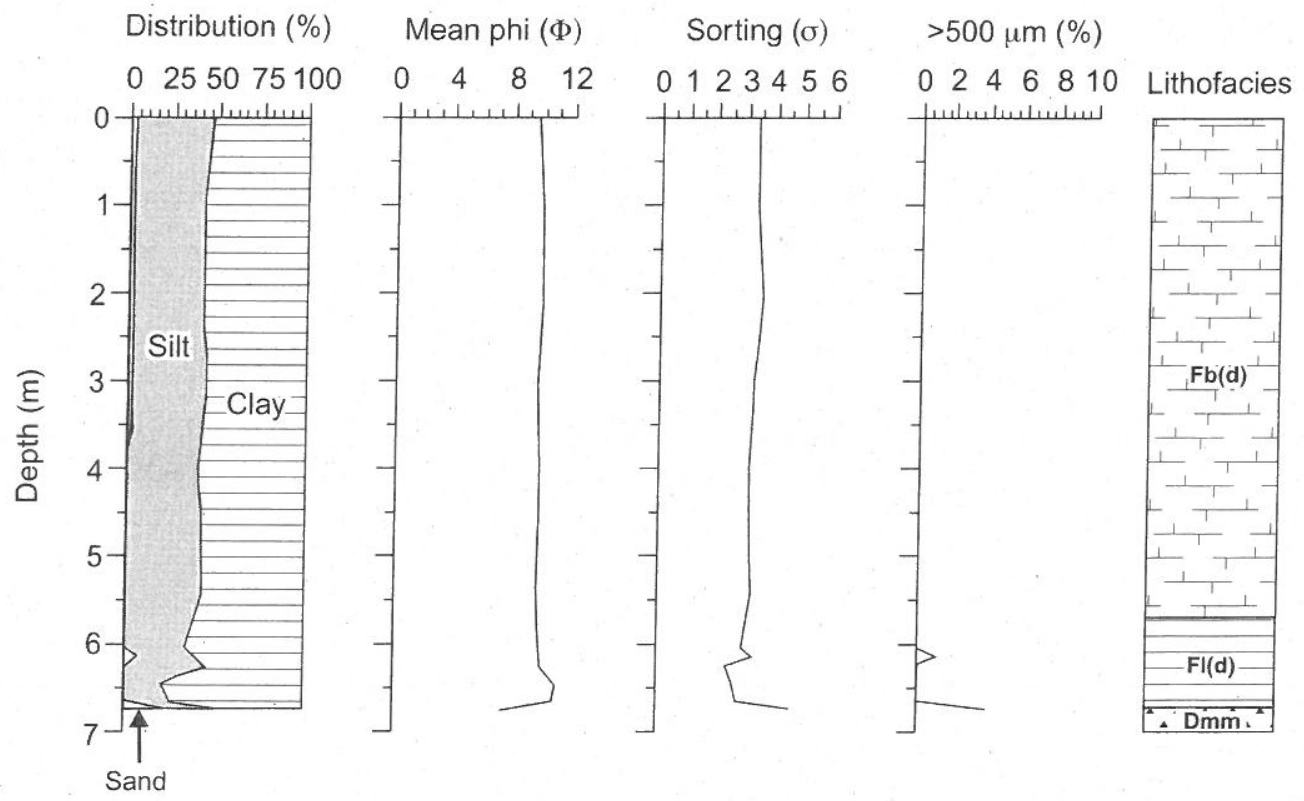

Fig. 8. Down-core grain size distribution, mean grain size, sorting and particles over $500 \mu \mathrm{m}$ from (a) PS2631, (b) PS2641, (c) PS2630, (d) PS2629, (e) PS2628 and (f) PS2627, outer Kejser Franz Joseph Fjord and inner continental shelf. Core locations are shown in Figure 1c. Lithofacies codes are explained in Table 3.

sediment is $<30 \mathrm{~m}$ thick and comprises acoustically opaque sediment or bedrock overlain by a drape of stratified sediment (facies 4) and a basin-length acoustically transparent sediment unit (facies 2) (Figs 4 \& 5b). Transparent to stratified sediment (facies 1a, 2) is present in the outermost sub-basin ( $>60 \mathrm{~m}$ thick), with a less than $12 \mathrm{~m}$ thick drape of stratified sediment (facies 4) along more down-fjord marginal regions of the basin. A thin drape of sediment $(<2 \mathrm{~m})$ (facies 4$)$ characterizes recent sedimentation in the outer fjord (Fig. 5b). 
c. PS2630

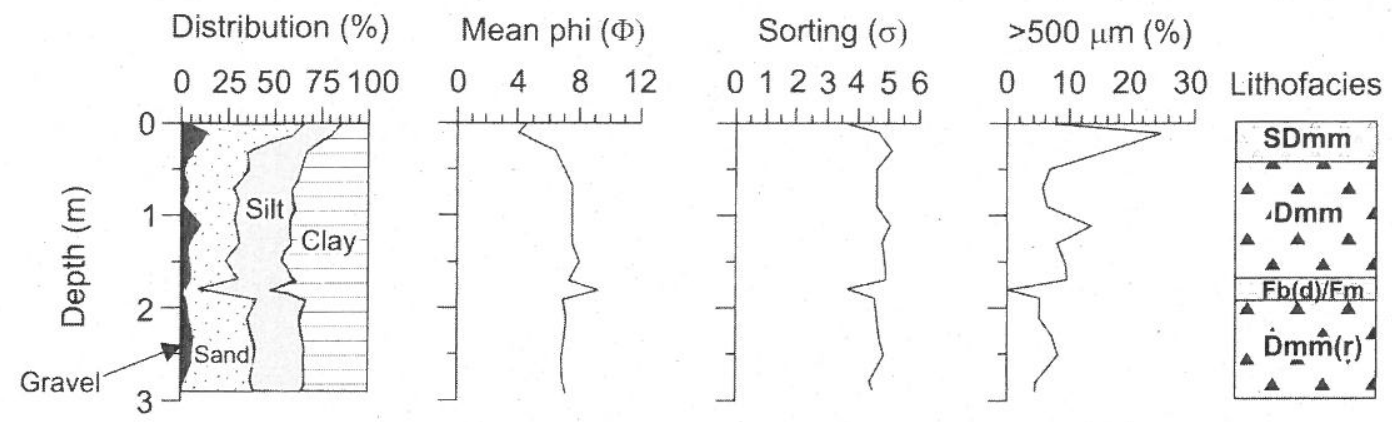

\section{d. PS2629}

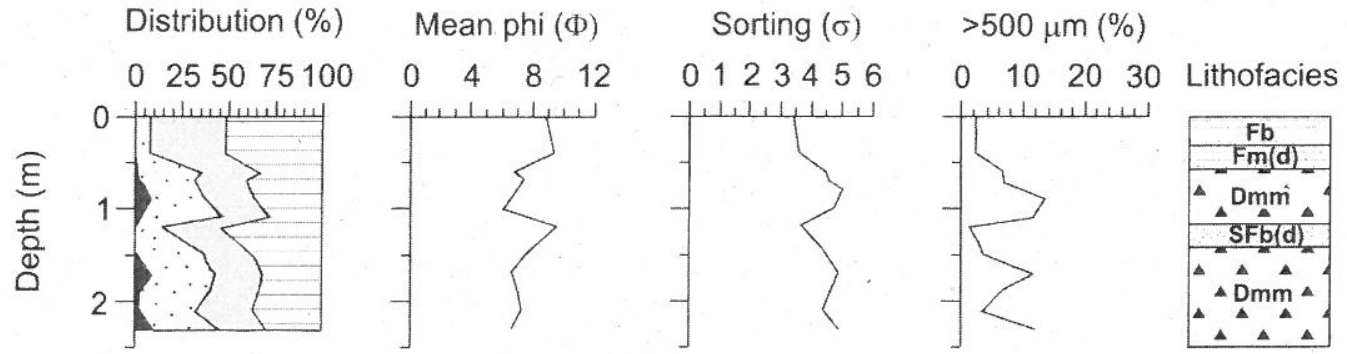

e. PS2628

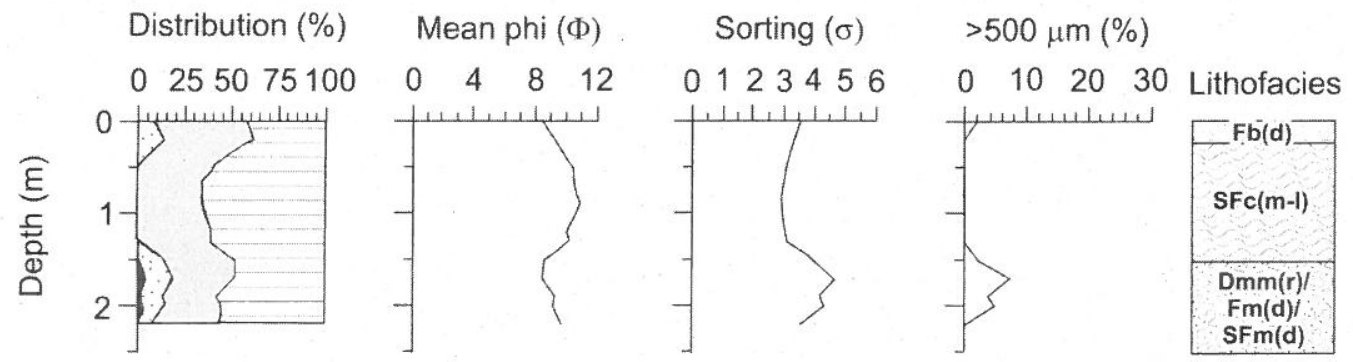

\section{f. PS2627}

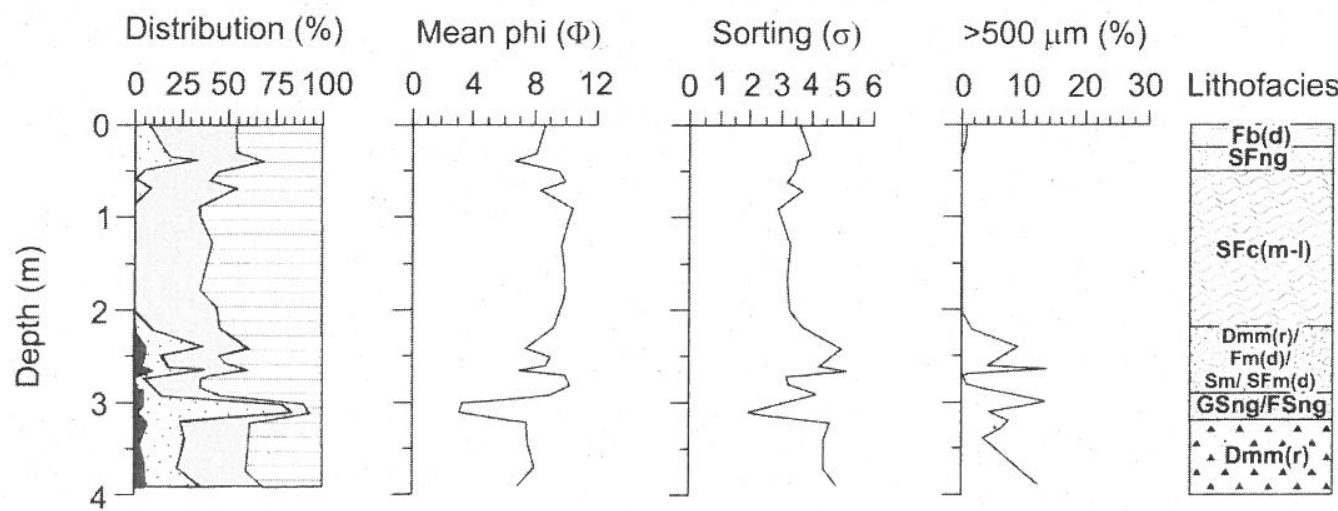

Fig. 8. continued. 
a

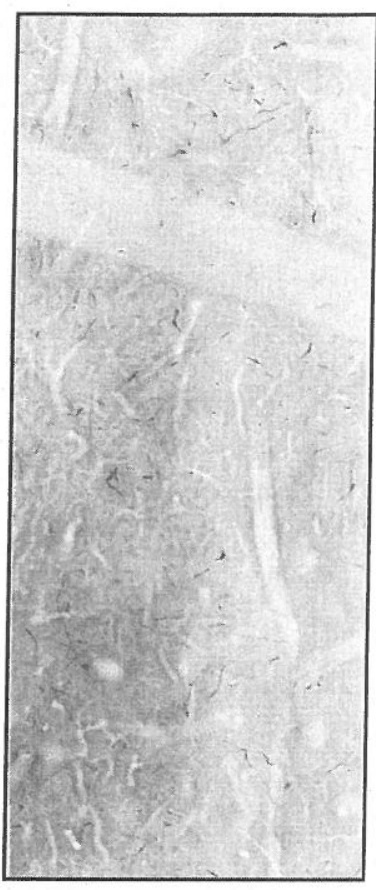

d

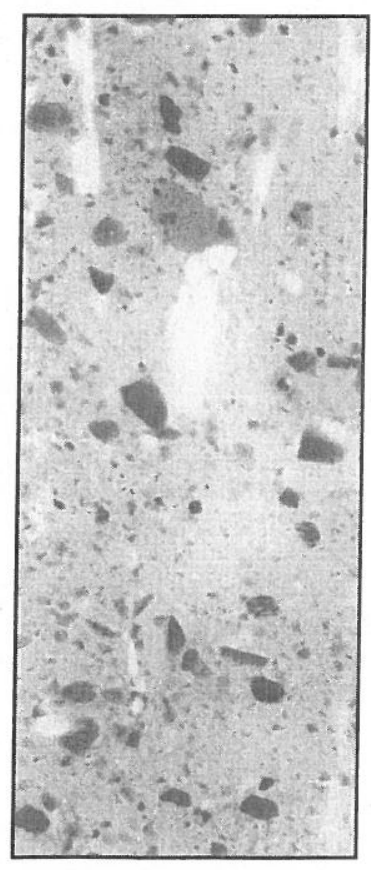

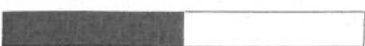

b

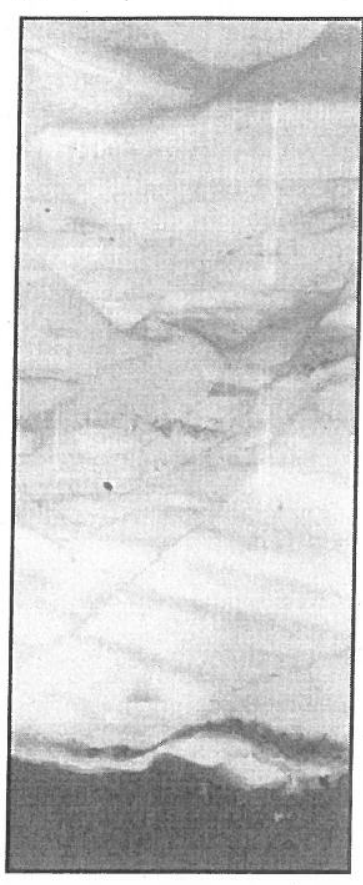

e

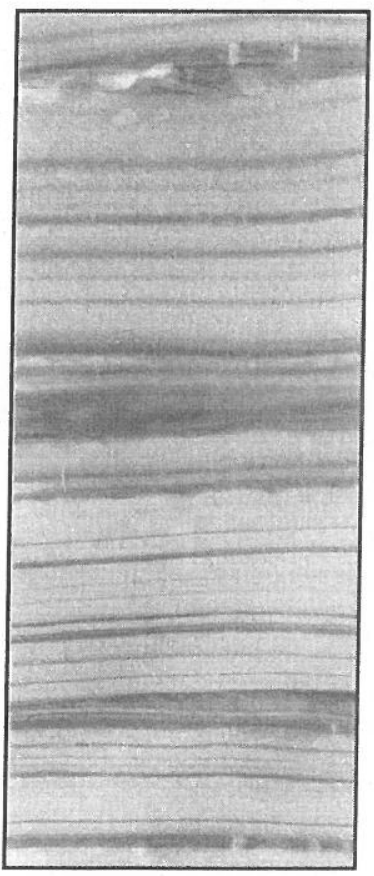

C

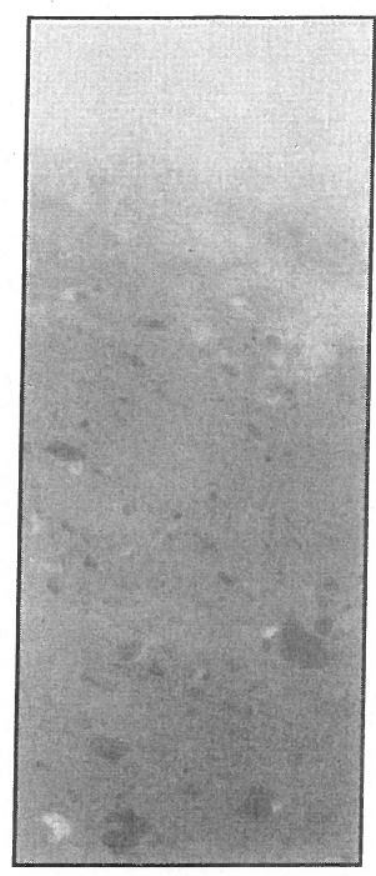

f

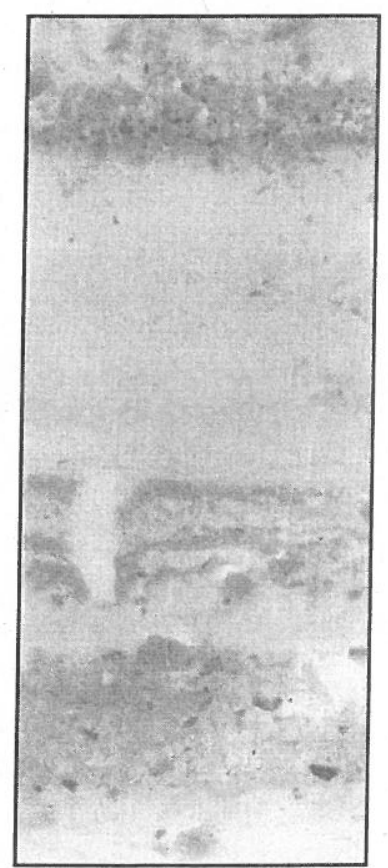

\section{$0 \quad \mathrm{~cm} \quad 6$}

Fig. 9. Core X-radiographs of representative lithofacies in this study. (a) Bioturbated mud (Fb) from PS2641. (b) Laminated mud (Fl) and massive diamicton (Dmm) from PS2641. (c) Resedimented massive diamicton (Dmmr) from PS2630. (d) Massive diamicton (Dmm) from PS2629. (e) Mud-sand couplets (SFc) from PS2627 and PS2628. (f) Interbedded dropstone mud/sandy mud (Fmd/SFmd) and massive diamicton (Dmm) in PS2627. 
Sediment within the deeper part of Fosters Bugt to the north of Bontekoe Island is up to 15 $\mathrm{m}$ thick and comprises a drape of stratified sediment with rare sea floor irregularities (facies 4), and rare ponded stratified sediment within some basins (facies 1a) (Fig. 4). The shallower regions of Fosters Bugt $(<300 \mathrm{~m})$ comprise a highly irregular sea floor (facies 3) (Fig. 4).

\section{Core sedimentology}

Core PS2631 was recovered from a stratified sediment drape in the outermost sub-basin of the outer fjord, and core PS2632 from the surface drape of the innermost sub-basin (facies 4) (Fig. 4). Both cores are dominated by bioturbated clay-rich mud $(\mathrm{Fb})$ with only a few clasts (Figs 6, $7 \&$ 8a). Bioturbation is characterized by pyritized Chondrites and rare Planolites burrows (Fig. 9a). The lowermost unit in PS2631 comprises laminated clay-rich mud $(\mathrm{Fl})$ with diffuse and planar parallel-to-wavy laminae disturbed by bioturbation, and rare clasts (Figs $6,7 \& 8 a)$.

Core PS2633 was recovered from stratified sediments draping the flanks of the mid-fjord basin (facies 4) (Fig. 4). The top half of the core consists of massive clay-rich mud (Fm) and small lenses of poorly sorted sand $(<10 \mathrm{~mm})$ (Fig. 6). The core-top comprises massive sandy mud with abundant clasts (SFmd) (Fig. 6). Laminated mud $(\mathrm{Fl})$ characterizes the lower half of the core comprising fine-to-crude scale, diffuse to well-defined, wavy-to-wispy-to-planar parallel laminae, with thin units of massive mud $(<5 \mathrm{~cm})$. Clasts, although rare, are relatively more abundant throughout PS2633 than in PS2631 and PS2632 (Fig. 7).

\section{Interpretation of acoustic and core sedimentology}

The ponded stratified sediments (facies 1a) within the basins of the fjord and Fosters Bugt are the result of deposition from sediment gravity flows and suspension settling (Syvitski 1989; Niessen \& Whittington 1997). Acoustically transparent sediment lenses of facies 2 are consistent with debris flow deposits derived from failure of sediment outside the basin (Laberg \& Vorren 1995; Dowdeswell et al. 1997b; Niessen \& Whittington 1997; King et al. 1998). The depositional processes, producing facies $1 \mathrm{a}$ and 2 , dominate sedimentation in the middle-outer fjord basins. Down-fjord progradation of sediment in the mid-fjord basin represents ice-proximal sedimentation derived from a temporarily stable ice-margin (cf. Ó Cofaigh et al. 2001). The drape of stratified sediment (facies 4) in the outer fjord and Fosters Bugt is derived from iceberg rafting and suspension settling (Syvitski 1989; Niessen \& Whittington 1997), and directly overlies acoustically opaque till or bedrock in the outermost fjord.

Cores PS2632, PS2633 and PS2631 recovered from the drape of glacimarine sediments in the middle-outer fjord (facies 4) indicate that deposition of fine-grained muds by meltwater processes greatly overwhelms the supply and release of debris by icebergs. Massive and bioturbated muds support sedimentation from meltwater under ice- or fjord margin-distal conditions (Elverhøi et al. 1983; Elverhøi \& Solheim 1983; Cowan et al. 1997). In contrast, the laminated muds indicate deposition from turbid meltwater plumes under comparatively more ice-proximal conditions (Powell 1983; Mackiewicz et al. 1984; Cowan \& Powell 1990; Cowan et al. 1997, 1999). Debris release from iceberg rafting is supported by the presence of small amounts of dispersed clasts (PS2631, PS2632 and PS2633), and sandy mud with clasts and lenses of poorly sorted sand (PS2633). An increase in IRD content up-fjord reflects the increasing proximity to tidewater glaciers in the inner fjords (Fig. 7). The highly irregular sea floor and acoustically homogeneous sediment (facies 3) in water depths of less than $300 \mathrm{~m}$ indicate that icebergs scoured the sea floor as they drifted through the fjord (cf. Dowdeswell et al. 1993, 1994a).

\section{Continental shelf}

\section{Sediment thickness and acoustic facies distribution}

The inner-middle shelf and the shelf break comprises a highly irregular sea floor and acoustically homogeneous sediment (facies 3) (Figs 4, 10a \& 11). A drape of stratified sediment $(<10 \mathrm{~m}$ thick; facies 4) overlies acoustically opaque sediment or bedrock in the inner shelf bathymetric deep (Figs $4 \& 10 \mathrm{~b}$ ). A drape of surface sediment (up to $4 \mathrm{~m}$ thick; facies 4) extends across an irregular topography from a prominent bathymetric high on the midshelf (see below) to the outer shelf. The surface drape is underlain by stratified sediment (facies $1 \mathrm{~b})$ in the region extending $2 \mathrm{~km}$ from the midshelf bathymetric high, and acoustically transparent to crudely stratified sediment of variable extent and thickness ( $<10 \mathrm{~m}$; facies 5$)$ across the remaining shelf (Figs $4 \& 11$ ). 


\section{Middle shelf ridge}

A wedge-shaped bathymetric high composed of acoustically homogeneous sediment (facies 3 ) is located on the inner-middle shelf (Figs 4 \& 11). The surface of this ridge is highly irregular. The ridge is $c$. $50-60 \mathrm{~m}$ in height and is bounded by a low gradient inner-shelf facing slope that merges with the eastern flank of the inner-shelf bathymetric deep, and a steeper outer-shelf facing margin $\left(3^{\circ}\right)$ (Fig. 11). The lower part of the steep outer-shelf facing margin is covered by a thin drape of sediment (facies 4).

\section{Core sedimentology}

Core PS2641 was recovered from the drape of sediment in the inner shelf deep (facies 4) (Figs $4 \& 10 \mathrm{~b})$. The core is dominated by bioturbated mud facies $(\mathrm{Fb})$ comprising pyritized Chondrites and Planolites burrows, and rare clasts (Figs 6, $8 \mathrm{~b} \& 9 \mathrm{a})$. This facies is underlain by laminated mud (Fl) with cyclically intercalated, millimetrescale, planar-parallel, silty mud and clayey mud laminae, and contains only rare clasts (Figs 6 \& $9 \mathrm{~b})$. The base of the core comprises massive, matrix supported diamicton (Dmm) with a sharp and irregular upper contact (Figs 6, 8b \& 9b).

Core PS2630 was recovered from stratified sediment (facies $1 \mathrm{~b}, 4) 1 \mathrm{~km}$ in front of the midshelf ridge (Figs $4 \& 11 \mathrm{~b}$ ). The top $30 \mathrm{~cm}$ of the core comprises massive sandy gravelly diamicton ( $13 \%$ gravel, $63 \%$ sand), separated via an indistinct contact from a massive muddy diamicton with dispersed to clustered clasts (Figs $8 \mathrm{c} \&$ 12a). A sharp and irregular contact separates the muddy diamicton from a thin unit of bioturbated mud $(\mathrm{Fb})$ which, in turn, is underlain by massive mud (Fm) (Figs 9c \& 12a). The core base comprises massive, muddy diamicton (Dmmr), with a fabric of inclined and aligned clasts in the top $10 \mathrm{~cm}$ of the unit, which become dispersed below (Figs 8c, 9c \& 12a).

\section{Interpretation of the acoustic record and core sedimentology}

Middle-shelf ridge: The prominent wedgeshaped morphology and acoustically homogeneous internal structure of the mid-shelf ridge are consistent with an origin as an ice-contact

Fig. 10. Parasound records of acoustic facies from the inner continental shelf. (a) Highly irregular sea floor with no sub-sea floor sedimentary structure (facies 3). (b) Thin glacimarine sediment drape (facies 4) overlying acoustically impenetrable sediment or bedrock within the inner shelf basin.
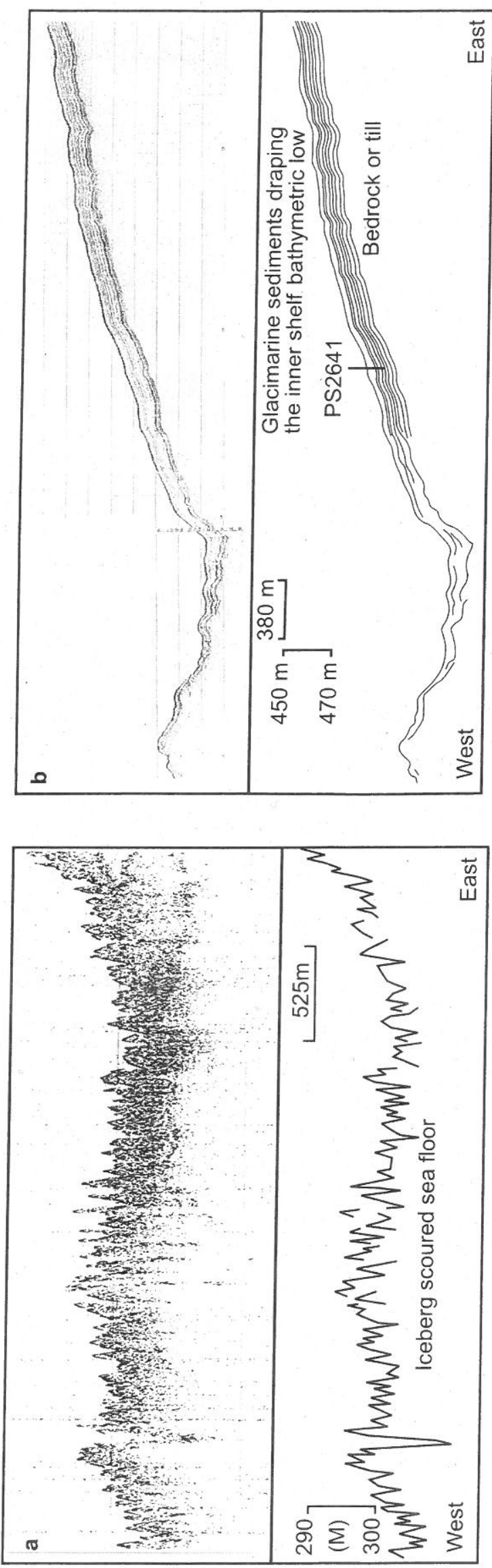


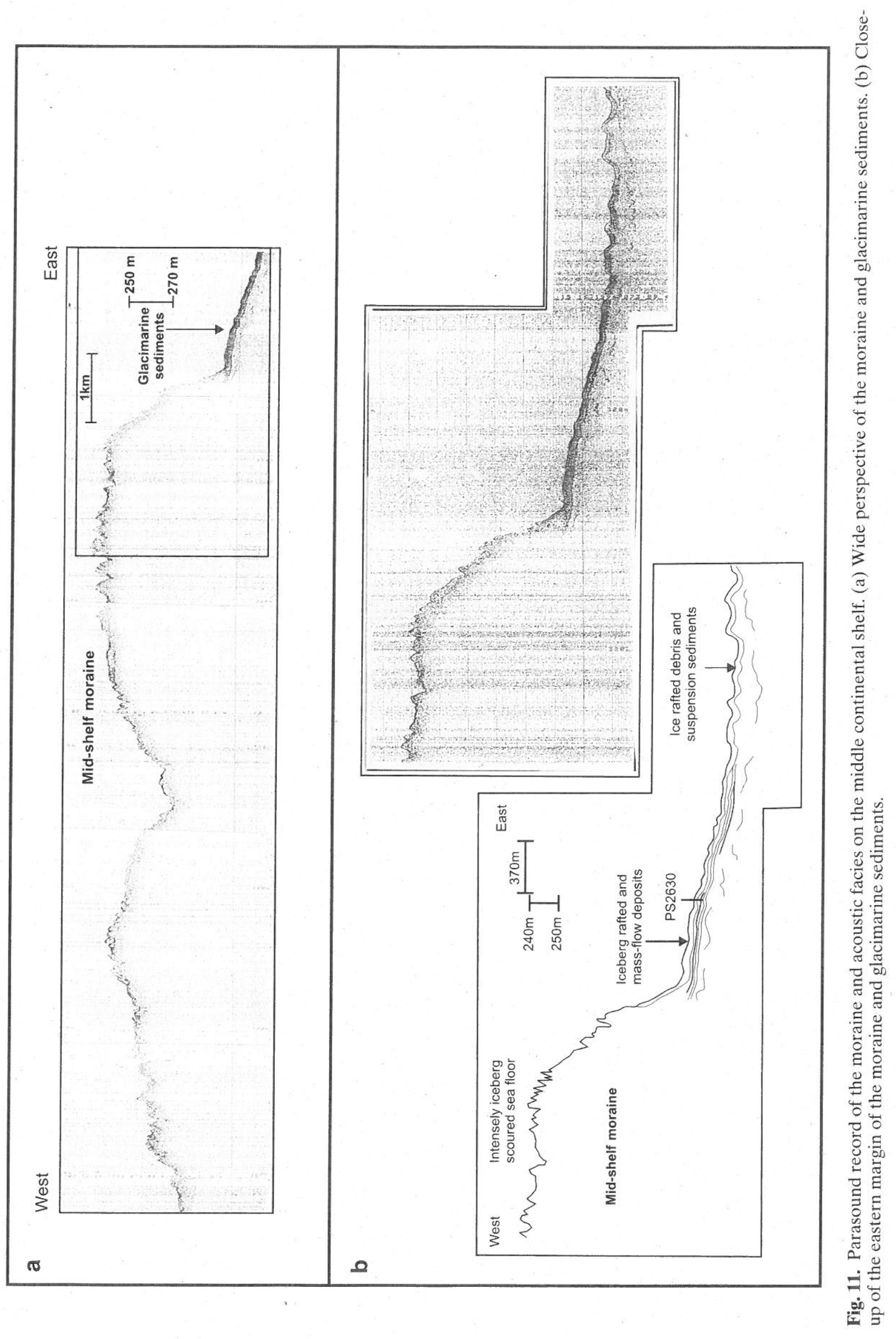




\section{a. PS2630 - Mid continental shelf}

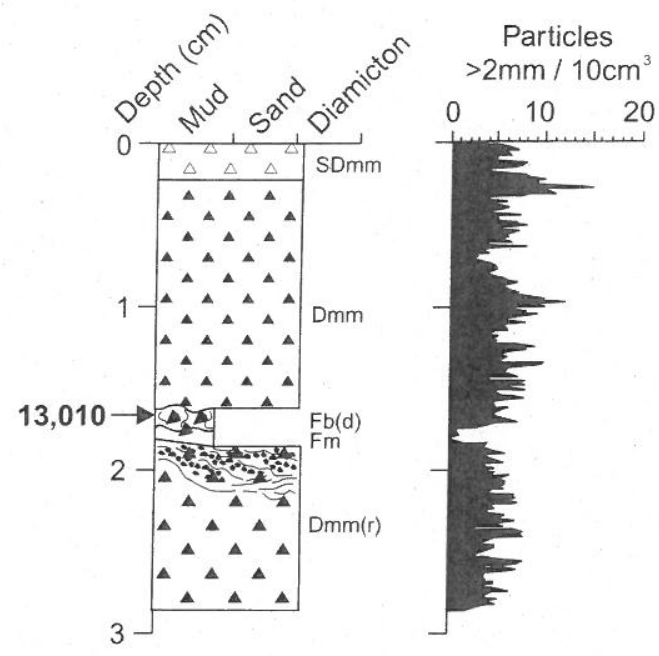

\section{PS2628 - Mid continental slope}

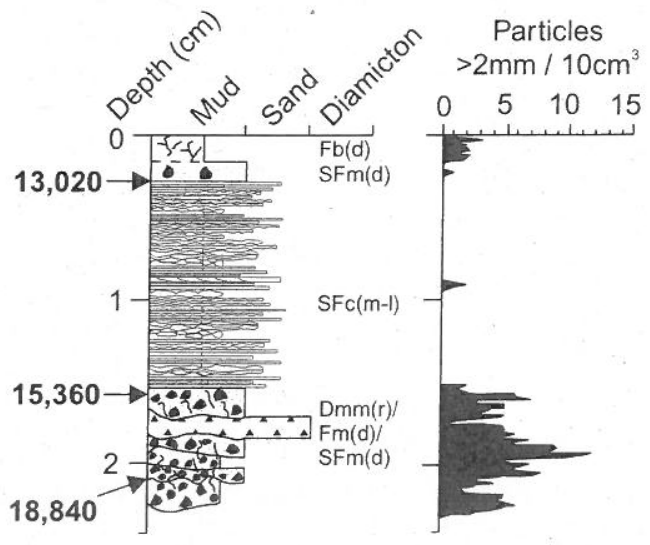

\section{b. PS2629 - Upper continental slope}

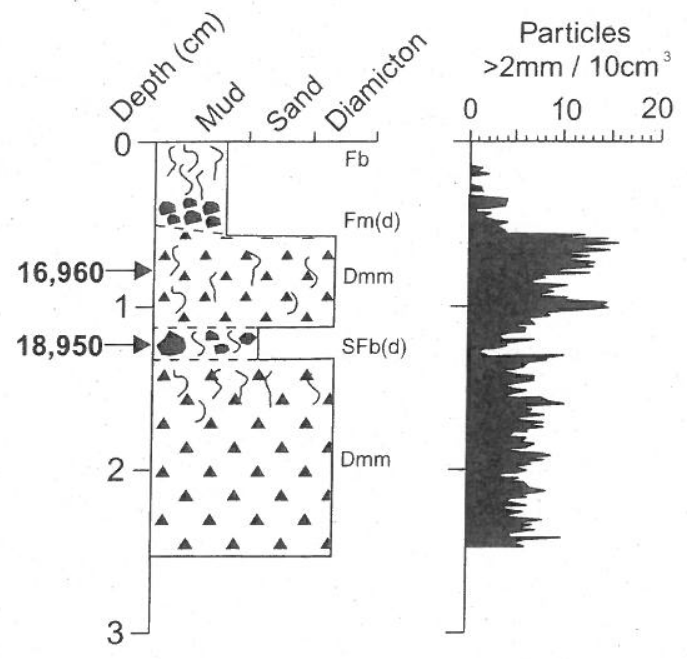

\section{d. PS2627 - Mid/lower continental slope}

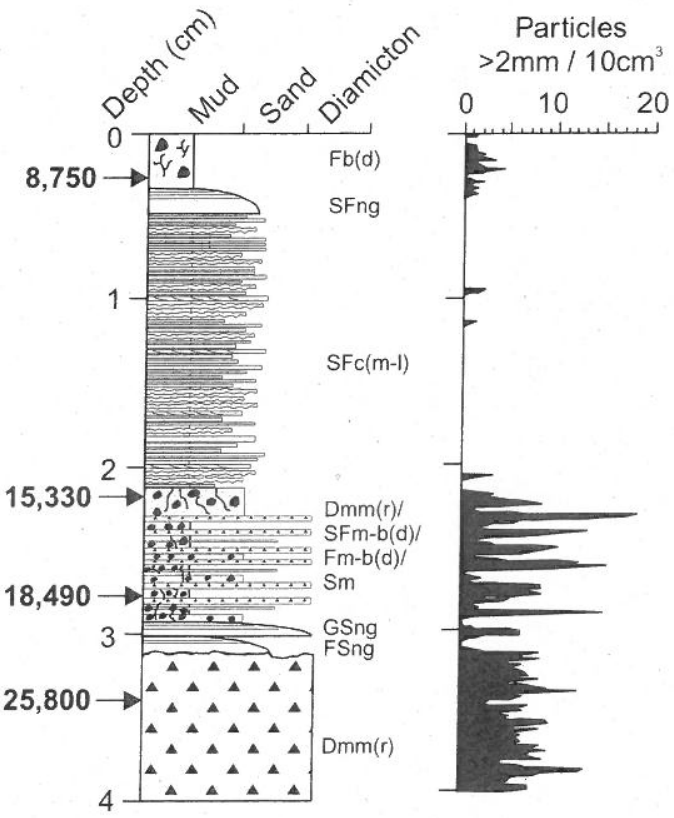

Chondrites

fD Planolites

31 Small burrows

$\notin$ Large burrows

Facies contacts:

-7radational Sharp
Erosive

Fig. 12. Sedimentological logs and coarse-particle counts (particles $>0.2 \mathrm{~cm} / 10 \mathrm{~cm}^{3}$ ) of (a) PS2630, (b) PS2629, (c) PS2628 and (d) PS2627, middle continental shelf and continental slope. Core locations are shown in Figure 1c. AMS radiocarbon dates $\left({ }^{14} \mathrm{C}\right.$ years BP) obtained from all cores are marked. Lithofacies codes are explained in Table 3. 
moraine (e.g. Syvitski et al. 1996b; Maclean 1997) (Fig. 11). The moraine is located directly east of the inner shelf deep, indicating that sediment may have been glacially excavated and redeposited from this region during the advance of grounded glacier-ice. Equally, the moraine may have formed by continual bulldozing of iceproximal glacigenic sediments forming a morainal bank (Powell \& Molnia 1989).

Acoustic and core sedimentology: The highly irregular sea floor and acoustically structureless sediment (facies 3) across the inner-middle shelf and shelf break indicates significant scouring by icebergs (Dowdeswell et al. 1993, 1994a). Core PS2641 reveals that glacimarine sediments draping acoustically opaque till or bedrock in the inner shelf deep comprise, in part, bioturbated mud deposited under ice- or fjord-distal conditions by meltwater escaping the East Greenland fjords (Elverhøi et al. 1983; Elverhøi \& Solheim 1983), and/or from the settling of bottom current remobilized shelf debris. The laminated mud facies $(\mathrm{Fl})$ indicates deposition from turbid-meltwater plumes with variable discharge under comparatively more ice-proximal conditions (Mackiewicz et al. 1984; Powell \& Molnia 1989; Cowan \& Powell 1990). Rare clasts indicate that iceberg rafting is relatively insignificant across the inner shelf. The basal massive muddy diamict is glacimarine in origin rather than a till on account of its unconsolidated nature and meltwater-derived $\delta^{18} \mathrm{O}$ isotope minima (see above).

The acoustically stratified sediment (facies $1 b, 4)$ deposited in front of the mid-shelf moraine is derived from ice-proximal sediment gravity flows, and rain-out/suspension settling. The upper massive diamicton in PS2630 corresponds to the drape of surface sediment (facies 4) extending from the moraine to the outer shelf, and is interpreted to result from the release of iceberg-rafted debris. Intense winnowing by the East Greenland Current has modified this sediment, producing a surface unit of sandy gravelly diamicton (cf. Mienert et al. 1992). The upper part of the underlying sequence of stratified sediment (facies 1b) comprises diamicton (PS2630), and the inclined and aligned clast fabric, sharp upper contact and fine-grained matrix supports an origin from cohesive debris flow (Walker 1992). The pinching out of reflectors in this sequence indicates the presence of a number of stacked massflow deposits. The origin of the acoustically transparent to crudely stratified sediment (facies 5) on the middle-outer shelf is uncertain on account of the spatially restrictive data coverage and absence of cores, but the crudely stratified nature suggests formation by ice-distal glacimarine sedimentation.

\section{Continental slope}

\section{Acoustic facies distribution}

The uppermost continental slope down to about $1200 \mathrm{~m}$ is dominated by acoustically structureless sediment (facies 6; Figs 4 \& 13a). Below $1200 \mathrm{~m}$ the mid-lower slope is characterized by stratified sediment (facies 1b) with isolated sediment lenses (facies 2) (Figs 13b \& c). Sediment lenses up to $7 \mathrm{~m}$ thick and orientated in a downslope direction (facies 2) are present close to the sea floor at $800-1300 \mathrm{~m}$ between the upper slope sediment and $\mathrm{mid} /$ lower slope stratified sediment resulting in a hummocky sea floor (Figs 4 \& 13b).

\section{Core sedimentology}

Core PS2629 was recovered from acoustically structureless sediment (facies 6) on the upper slope (Figs 4 \& 13a). The core-top comprises bioturbated clay-rich mud ( $\mathrm{Fb})$ and rare clasts, which are most abundant above the underlying diamicton (Figs 8d, 12b). A massive, poorly sorted diamicton facies (Dmm) dominates the core and comprises dispersed to clustered clasts (10\%) and more than $30 \%$ sand (Figs $8 d, 9 d$ \& $12 \mathrm{~b})$. The diamicton is separated into two units via gradational contacts by a biogenic-rich $(>50 \%$ ) bioturbated sandy mud (SFbd) with dispersed clasts (4\%), and up to $15 \%$ poorly sorted sand (Figs 8d \& 12b).

Cores PS2628 and PS2627 were recovered from stratified sediment (facies 1b) and sediment lenses (facies 2) on the middle-lower slope (Figs 4 \& 13c). Surface facies consist of biogenic-rich $(>30 \%)$ bioturbated clay-rich mud (Fb) (Fig. 12). The facies is underlain by a thick sequence of rhythmically-intercalated, sandmud couplets $(\mathrm{SFc})$. The couplets comprise a lower layer or lenses ( $<8 \mathrm{~mm}$ thick) of massive or planar/wavy parallel-to-cross laminated sandy or silty mud, and an upper layer $(<20 \mathrm{~mm}$ thick) of massive to weakly parallel laminated clayey mud (Figs 9e, 12c \& d). Climbing ripples and dewatering structures are rare. Contacts are sharp and well defined, with the basal contact of the couplet flat to undulating and in some cases erosive (Fig. 9e). A succession of thinly interbedded, massive muddy diamicton, massive to bioturbated sandy mud and massive mud dominate the lower half of both cores (Figs 9f, $12 \mathrm{c} \& \mathrm{~d}$ ). The muddy diamicton (Dmm) 


\section{a. Upperslope}

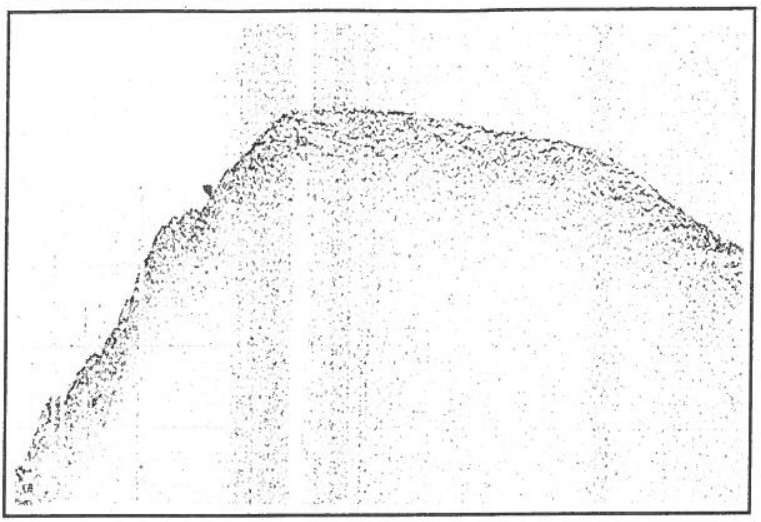

\section{b. Upper/mid slope}

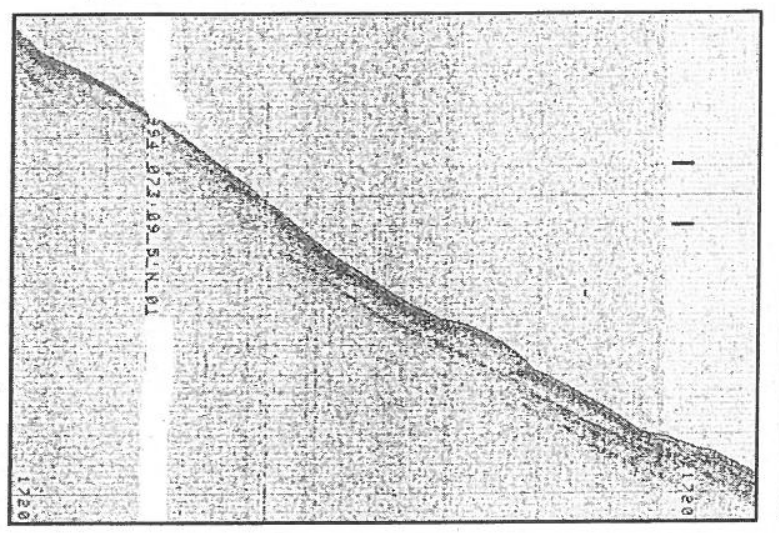

\section{c. Mid/lower slope}

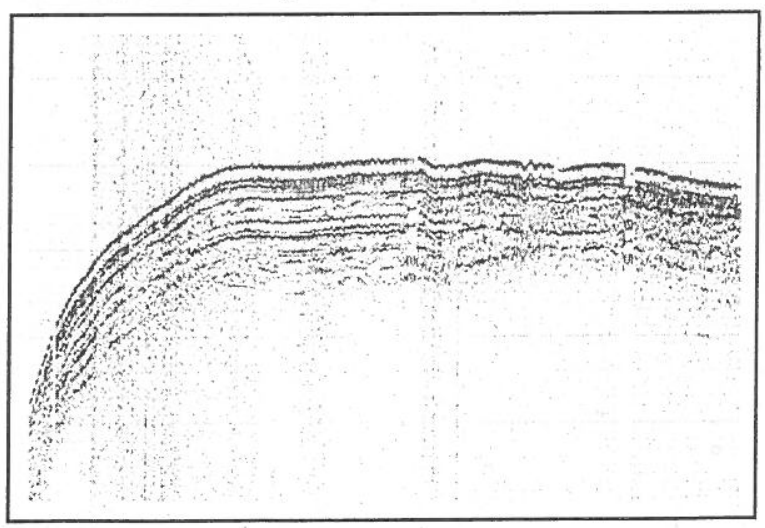

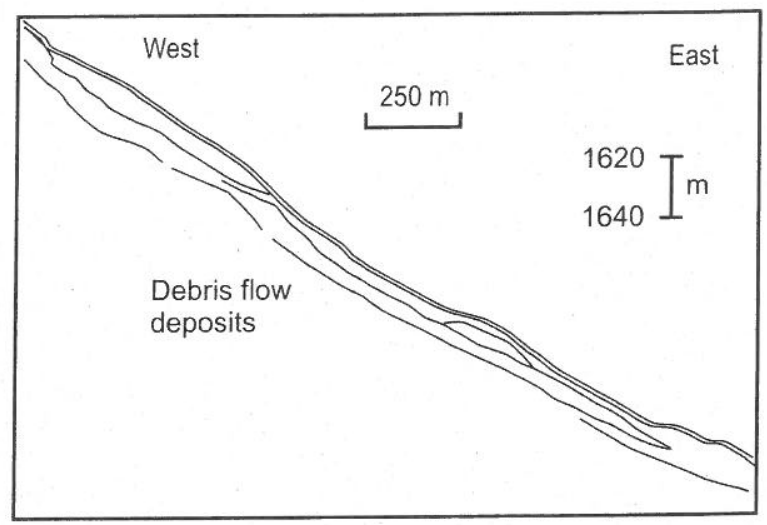
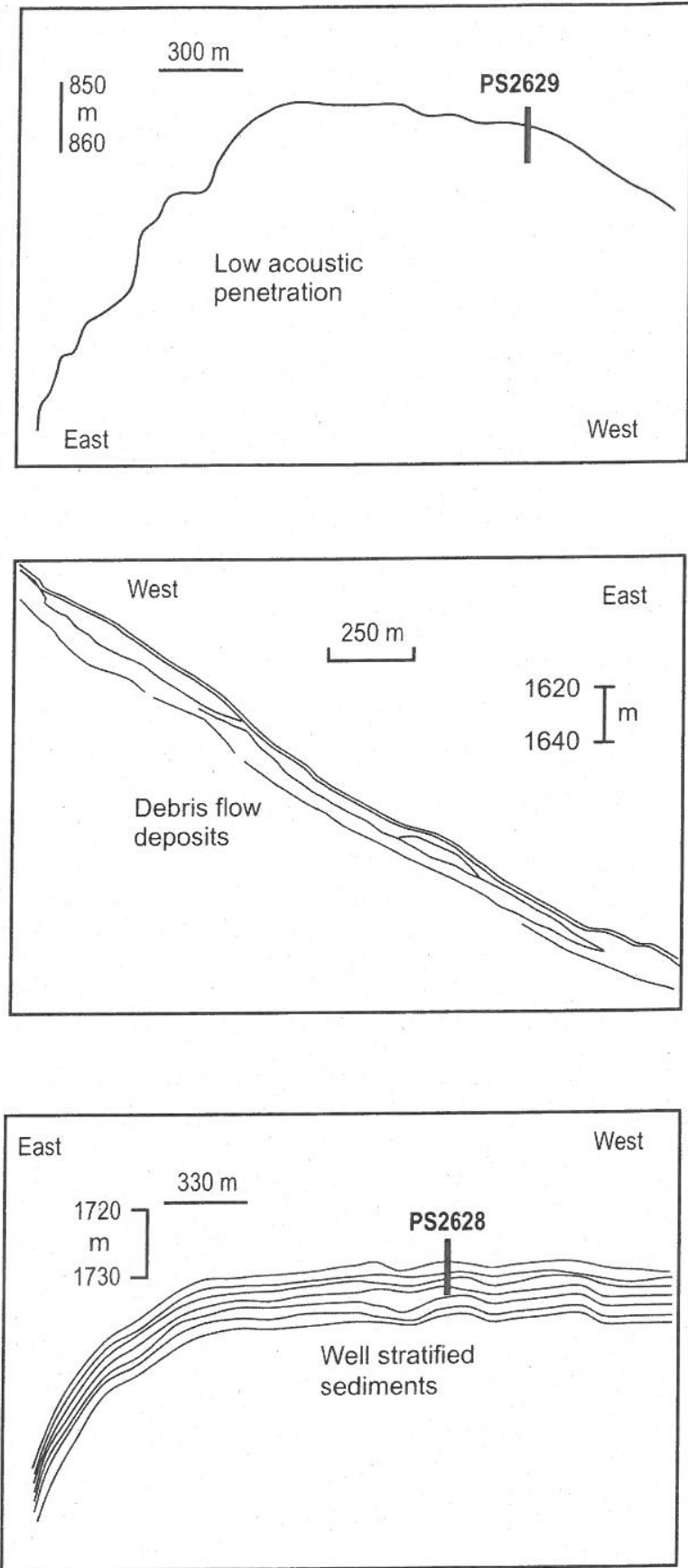

Fig. 13. Parasound records of acoustic facies from the continental slope. (a) Acoustically impenetrable sediments (facies 6) characterizing the upper slope. (b) Acoustically homogeneous sediment lobes (facies 2) overlain by a thin sediment drape (facies 4) on the upper-mid slope. (c) Acoustically stratified sediment (facies 1b) on the mid-lower slope. Horizontal and vertical scales are shown.

contains dispersed clasts and is bounded by sharp contacts. Sandy mud facies (SFmb) contain up to $20 \%$ dispersed clasts and poorly sorted sand (Figs $8 \mathrm{e} \& \mathrm{f}, 12 \mathrm{c} \& \mathrm{~d}$ ). The base of PS2627 comprises normally graded gravelly sand and muddy sand facies (GSng/SFng) and a thick, massive muddy diamicton (Dmm), all separated by sharp contacts (Figs 12c \& d).

Interpretation of acoustic and core sedimentological data: Acoustically structureless sediment (facies 6) on the upper slope is interpreted to 
reflect both a coarse-grained sediment texture, and a steep slope gradient (cf. Kuhn \& Weber 1993; Melles \& Kuhn 1993). Massive muddy diamicton with large numbers of clustered to dispersed clasts, interbedded with bioturbated sandy mud via gradational contacts in PS2629 indicates that iceberg rafting is an important depositional mechanism on the upper slope (cf. Dowdeswell et al. 1994a). Sandy mud facies supports a period of reduced IRD supply coupled to an increase in hemipelagic sedimentation. Down-slope orientated sediment lenses (facies 2) on the upper-mid slope transitional region are consistent with debris flow deposits (Laberg \& Vorren 1995; Dowdeswell et al. 1997b; King et al. 1998), supporting sediment failure and mass-flow on the upper slope. Recent sedimentation on the upper slope comprises thin hemipelagic bioturbated mud (Fb) (PS2629). A gradual decrease in the number of clasts from the diamicton through the surface mud represents a gradual cessation in IRD delivery to the upper slope (Fig. 8).

Stratified and lens-shaped sediment (facies $1 \mathrm{a}, 2)$ on the middle-lower slope indicates deposition from sediment gravity flow, iceberg rafting and suspension settling producing interbedded fine- and coarse-grained facies (PS2628 and PS2627). Surface bioturbated muds represent recent hemipelagic sedimentation with only limited deposition of IRD. The sedimentary characteristics of the sand-mud couplet facies are consistent with down-slope currents (distal turbidites) and intervening periods of hemipelagic sedimentation (Piper 1978; Stow \& Shanmugam 1980; Hill 1984; Yoon et al. 1991; Anderson et al. 1996). The lower sections of PS2628 and PS2627 are sedimentologically more variable. Bioturbated mud and sandy muds contain a high biogenic content and rare to common clasts, indicating hemipelagic sedimentation and the release of low but variable amounts of IRD. Hemipelagic sedimentation is punctuated by episodic deposition of massive diamicton by cohesive debris flows (Hampton 1972; Middleton \& Hampton 1976; Laberg \& Vorren 1995; King et al. 1998). Normally graded sandy/gravelly facies indicate further deposition by turbidity currents (Bouma 1962; Walker 1992). A debris flow origin for the diamicton is confirmed by the correspondence of thicker units to sediment lenses (facies 2) within acoustic records.

\section{Discussion: Late Quaternary sedimentary record}

\section{Late Weichselian ice-sheet extent (LGM)}

A thin veneer of Holocene and Late Weichselian glacimarine sediment overlying acoustically impenetrable till or bedrock on the inner shelf, Fosters Bugt and outer Kejser Franz Joseph Fjord indicates that active, grounded glacier-ice of the Greenland Ice Sheet occupied the fjord and extended onto the inner shelf during the LGM, removing pre-existing sediment cover (Fig. 14). The existence of a floating ice shelf within the Kejser Franz Joseph Fjord and across the inner shelf can therefore be ruled out, as this would be incapable of eroding sediment. However, our data are inconclusive in terms of whether the ice-sheet margin was floating or grounded on the middle continental shelf, although Funder et al. (1998) suggest that East Greenland ice masses formed ice shelves.

The prominent mid-shelf moraine consisting of unlithified sediment marks the margin of the grounded palaeo-Greenland ice sheet on the shelf. This moraine is directly overlain by a thin iceberg-rafted diamicton unit that dates 13000 ${ }^{14} \mathrm{C}$ years BP (PS2630; Figs 11 \&12a), indicating that the moraine is probably Late Weichselian in age. The moraine therefore represents either the maximum ice-sheet extent during the LGM or marks a recessional position during Late Weichselian deglaciation. Although it is conceivable that the moraine could mark a recessional position of an ice margin retreating from the shelf break, current evidence indicates that the moraine is more likely to represent the outermost limit of the LGM ice sheet for the following related reasons. (1) Terrestrial geological evidence indicates that the Greenland Ice Sheet reached the inner-middle shelf during the LGM in this region (Hjort 1981; Funder 1989; Funder \& Hansen 1996; Funder et al. 1998). (2) There is an apparent absence of icecontact features on acoustic records from the outer shelf, suggesting glacier-ice probably terminated inshore of the shelf break. (3) There is an apparent absence of major debris flows, trough mouth fans and large-scale sliding in this region of the East Greenland continental slope (Mienert et al. 1993, 1995). Such features are characteristic of regions around the Polar North Atlantic where ice sheets extended to the shelf break during glacial maxima (Laberg \& Vorren 1995; Dowdeswell et al. 1996, 1998, 2002; Vorren et al. 1998).

Glacier extent during the LGM in East and NE Greenland appears to have been more 
restricted (Hjort 1981; Funder 1989; Funder \& Hansen 1996) when compared to the region south of Scoresby Sund where glacier-ice extended to the shelf break during the LGM (e.g. Mienert et al. 1992; Andrews et al. 1996). This contrast probably reflects an increase in aridity north of Scoresby Sund in response to cyclonic drift tracks delivering precipitation to SE Greenland prior to moving out into the Polar North Atlantic away from the East Greenland coast (Funder \& Hansen 1996; Funder et al. 1998).

\section{Continental slope sedimentation during the Late Weichselian glaciation}

The continental slope is characterized by significant sediment flux and deposition of coarsegrained lithofacies in response to the advance of the Greenland Ice Sheet onto the continental margin (Fig. 2). Sediment flux is highest on the upper slope $\left(29-65 \mathrm{~g} \mathrm{~cm}^{-2} \mathrm{ka}^{-1} ; 30 \mathrm{~cm} \mathrm{ka}^{-1}\right)$, reflecting the more proximal location relative to the palaeo-ice sheet margin on the continental shelf, and decreases on the middle-lower slope (16-24 $\left.\mathrm{g} \mathrm{cm}^{-2} \mathrm{ka}^{-1} ; 16-17 \mathrm{~cm} \mathrm{ka}^{-1}\right)$. The upper slope is characterized by coarse-grained sediment, and core PS2629 indicates that this sediment is composed, in part, of iceberg-rafted diamicton with high concentrations of IRD. This suggests that sedimentation on the upper slope during the Late Weichselian was dominated by the release of debris from a significant number of icebergs calved from the Greenland Ice Sheet with a further contribution from marine sources and distal meltwater. The coarse-grained content of the diamicton exceeds $30 \%$ suggesting modification by bottom currents associated with the East Greenland Current (Mienert et al. 1992). The presence of dropstone sandy mud and mud-rich facies with low amounts of IRD on the mid to lower slope (PS2628 and PS2627) indicates that the release of IRD is greatly reduced and hemipelagic sedimentation dominates. This spatial difference in the amount of IRD between the upper slope and the mid-lower slope reflects either: (1) a downslope gradient in the number of icebergs traversing the slope, possibly in response to the southward flowing EGC confining most of the icebergs to the upper slope, or (2) the more iceproximal setting of the upper slope relative to the LGM ice margin where a large amount of debris is deposited from icebergs.

Sediment gravity flows redistribute sediment down the East Greenland slope. The acoustically impenetrable sediment characterizing the upper slope reflects the coarse grain size of ice-rafted diamicts and subaqueous mass-flow deposits in this region (cf. Kuhn \& Weber 1993; Melles \& Kuhn 1993). Debris flow lobes on the upper-mid slope region indicate that mass-flows were derived from upper slope sediment instability and failure of rapidly accumulating, iceberg rafted sediment. Debris flows transport sediment over variable distances down the slope where it can cross from the upper slope region of acoustically impenetrable sediment into the area of acoustically stratified sediment on the mid- to lower-slope. On the mid- to lower slope, episodic debris flow activity punctuated intervals of more quiescent, hemipelagic sedimentation, resulting in a sequence of diamicts $(\mathrm{cm}-$ to metre-scale thickness) interbedded with dropstone sandy mud and laminated, massive or stratified mud facies. Turbidites are also present on the mid-lower slope, forming graded sand and gravel facies produced from episodic turbidity currents that are triggered by debris flow activity further up slope (cf. Hampton 1972).

\section{Large-scale sedimentation on the East Greenland continental margin}

Spatial differences in the style of large-scale sedimentation around the margins of the Polar North Atlantic have been attributed to contrasts in ice-sheet dynamics, notably with respect to ice-sheet extent and the rate at which sediment is delivered to the continental slope (Laberg \& Vorren 1995; Dowdeswell et al. 1996, 1998; Vorren et al. 1998). The sedimentary record in this study covers only a limited area of the East Greenland slope and is, therefore, placed within a regional context using published GLORIA imagery and geological data from the slope and the abyssal plain of the Greenland Sea (cf. Mienert et al. 1993, 1995; Dowdeswell et al. 2002; Ó Cofaigh et al. 2002).

Sedimentation is greatest on the central East Greenland slope during full-glacial periods in response to ice-sheet advance across the continental shelf. LGM sedimentation rates of up to $30 \mathrm{~cm} \mathrm{ka}^{-1}$ are recorded on the slope and contrast with Holocene rates of less than $4 \mathrm{~cm} \mathrm{ka}^{-1}$. Geological evidence presented in this study and from other work in East Greenland (e.g. Dowdeswell et al. 1994b; Funder 1989; Funder et al. 1998) indicates that the Greenland Ice Sheet has exhibited relatively minor fluctuations between Late Quaternary glacial and interglacial periods. These fluctuations limited the amount of sediment transferred to the East Greenland slope, resulting in a sedimentstarved environment relative to other margins of the Polar North Atlantic where ice sheets 


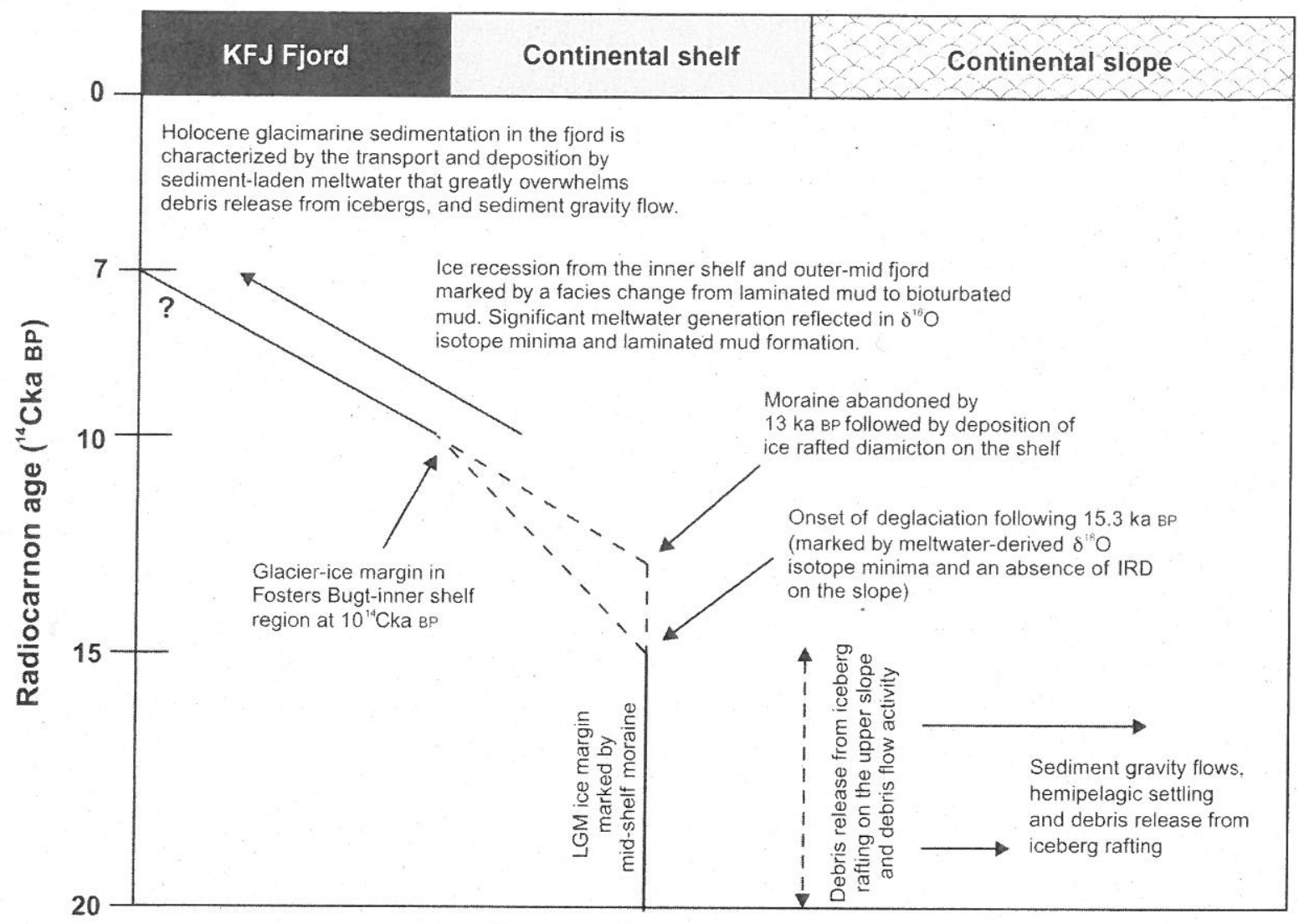

Fig. 14. Summary time-distance diagram of the Late Weichselian and Holocene glacial and sedimentation history of Kejser Franz Joseph Fjord and adjacent continental margin.

reached the shelf break and delivered sediment directly to the slope at rates up to, and possibly exceeding, $170 \mathrm{~cm} \mathrm{ka}^{-1}$ (Laberg \& Vorren 1996; Vorren et al. 1998; Dowdeswell et al. 1996, 1998; Solheim et al. 1998).

The East Greenland margin north of $72^{\circ} \mathrm{N}$ is characterized by a network of submarine channels that extend from the upper continental slope to the abyssal plain of the Greenland Sea, and the apparent absence of major debris flow lobes or a trough-mouth fan (Mienert et al. 1993, 1995; Dowdeswell et al. 2002). This is confirmed by our core and acoustic records showing that debris flows are confined mainly to the upper slope and do not form the main architectural sediment body so typical of slopes characterized by trough-mouth fans (e.g. Laberg \& Vorren 1995; Dowdeswell et al. 1997 b; King et al. 1998). Sediment cores and acoustic records in this study were recovered from immediately upslope of the channels and also from the upper regions of the channel system itself. Diamicton, sand and mud facies in cores, and sediment lobes in the acoustic records, indicate episodic down-slope transport of coarse-grained sediment by debris flows and turbidity currents, derived from mass failure of upper slope sediments.

Sediment gravity flows sourced from the upper slope are likely to have fed into the deepwater channel systems. The passage of turbidity currents through the channel system is indicated by the presence of sandy and muddy turbidite facies in cores recovered from the channel system further downslope (Ó Cofaigh et al. 2002). This evidence suggests that sediment gravity flows contributed to the formation of the channel system, possibly in conjunction with dense brines cascading down the slope following their rejection during the formation of sea ice across the East Greenland shelf (Dowdeswell et al. 1996, 1998, 2002).

\section{Onset of Late Weichselian deglaciation}

The initial onset of deglaciation of the Greenland Ice Sheet is indicated by a distinct $\delta^{18} \mathrm{O}$ isotope minima after $15300{ }^{14} \mathrm{C}$ years $\mathrm{BP}$ on the continental slope (PS2627) attributed to a major pulse of low-saline meltwater (Fig. 14). A 
meltwater event following 15800 years BP is also recorded in oxygen isotope records from further south along the East Greenland continental margin (Nam et al. 1995; Nam 1996). The similarity in timing indicates that meltwater production was a regional phenomenon and that the onset of deglaciation in East Greenland was broadly synchronous. The timing of deglaciation is supported by oxygen isotope data from the Renland Ice Core (Scoresby Sund region), which shows termination of the last glacial period at c. $15000{ }^{14} \mathrm{C}$ years BP (Johnsen et al. 1992). Meltwater spikes in isotope records from the Fram Strait and Norwegian Sea indicate that the deglaciation of ice sheets surrounding these regions occurred slightly later, beginning after $15000{ }^{14} \mathrm{C}$ years BP (e.g. Jones \& Keigwin 1988; Sarnthein et al. 1992; Elverhøi et al. 1995; Hald et al. 1996; Hebbeln et al. 1998). Initial deglaciation in the Eurasian Arctic occurred earlier at 15800 years BP (Stein et al. 1994a,b).

Deglaciation of the Greenland Ice Sheet further to the north in East and NE Greenland may have sourced these meltwaters with subsequent transport south in the East Greenland Current (cf. Stein et al. 1996). Meltwaters influencing the East Greenland continental margin may be associated, in part, with the decay of the Russian Arctic and Svalbard-Barents Sea ice sheets (Stein et al. 1994a,b; Nam et al. 1995). The influence of meltwater across the continental slope had terminated by $13000{ }^{14} \mathrm{C}$ years BP, probably in response to continued retreat of the ice-sheet margin.

There is an apparent absence of diagnostic sedimentary and acoustic facies on the middle-outer shelf that could provide information on the nature (continual or staggered retreat), mechanism (iceberg calving versus melting) and rate of ice sheet recession in East Greenland. However, a thin unit of icebergrafted diamicton drapes the front of the middleshelf moraine indicating that the ice sheet had abandoned the middle shelf before 13000 ${ }^{14} \mathrm{C}$ years BP (Fig. 14).

\section{Sedimentation on the continental shelf and slope during Late Weichselian deglaciation}

An abrupt termination in both IRD delivery and deposition of coarse-grained sediment gravity flow deposits across the East Greenland slope occurs concomitantly with the onset of deglaciation after $15300{ }^{14} \mathrm{C}$ years BP. Both parameters are consistent with the slope becoming an increasingly ice-distal environment, and with an associated decrease in the flux of glacial sediment to the slope, concomitant with icesheet retreat. Reduced sediment flux would result in greater sediment stability on the slope, thereby preventing sediment gravity flows and the deposition of coarse-grained lithofacies. The East Greenland Current may have confined icebergs to the shelf and uppermost slope (possibly in response to an increase in current velocity), thereby preventing both the drift of icebergs over the slope and deposition of IRD.

Hemipelagic sedimentation dominates the upper slope during Late Weichselian deglaciation with deposition of dropstone sandy mud (PS2629). The mid- to lower slope between 15300 and $13000{ }^{14} \mathrm{C}$ years BP is characterized by the deposition of finely interbedded sand-mud couplets (47-98 $\mathrm{g} \mathrm{cm}^{-2} \mathrm{ka}^{-1}$; $51-79 \mathrm{~cm} \mathrm{ka}^{-1}$ ) by a combination of downslope current activity and hemipelagic settling. This lithofacies has been observed on the slope off western Spitsbergen where it is associated with the growth and decay of the Barents Sea Ice Sheet (Andersen et al. 1996). These currents may have been derived from relatively smallscale sediment failure on the upper slope. Alternatively, downslope currents could be associated with movement of dense brines down the continental slope following their rejection during increased seasonal sea-ice formation (cf. Dowdeswell et al. 1998). Hemipelagic settling dominates sedimentation after $13000{ }^{14} \mathrm{C}$ years BP with reduced sediment flux $\left(<3 \mathrm{~g} \mathrm{~cm}^{-2} \mathrm{ka}^{-1} ;<4 \mathrm{~cm} \mathrm{ka}^{-1}\right)$.

Sedimentation proximal to the middle-shelf moraine before 13000 years BP is dominated by debris flow diamicton (PS2630) but it is uncertain how far this mass-flow activity extends back in the Late Weichselian. Iceberg-rafted diamicton is deposited across the shelf in regions proximal to the moraine between 13000 and $10000{ }^{14} \mathrm{C}$ years BP and may extend across the outer shelf. This facies post-dates the moraine and indicates that the ice sheet had retreated from the middle-shelf by $13000{ }^{14} \mathrm{C}$ years $\mathrm{BP}$, and that ice-mass loss was by iceberg calving. Very light $\delta^{18} \mathrm{O}$ values corresponding to this diamicton drape indicate significant meltwater production associated with either melting of icebergs or the ice sheet itself.

\section{Late Weichselian-Early Holocene deglaciation of the inner shelf and fjord system}

Deglaciation of the inner continental shelf and fjord is marked by an up-sequence facies change (PS2633, PS2631 and PS2641) from laminated mud to bioturbated mud, representing 
meltwater deposition and a progressive shift from ice-proximal to ice-distal conditions during ice-sheet recession (cf. Svendsen et al. 1992). These sediments directly overlie acoustically opaque till or bedrock on the inner shelf and in the outer fjord, and they represent grounded ice-sheet conditions as opposed to an ice shelf. Significant production of low-saline meltwater during deglaciation of the inner shelf and outer fjord is confirmed by a prominent $\delta^{18} \mathrm{O}$-spike in isotope records corresponding to the laminated mud facies on the inner shelf (PS2641). The abrupt termination of both the $\delta^{18} \mathrm{O}$-minima and deposition of laminated mud supports rapid deglaciation and establishment of ice-distal conditions. Deposition of fine-grained lithofacies dominates ice recession, indicating that ice mass-loss is controlled by ablation with significant production of meltwater. The low concentrations of IRD within these lithofacies indicate that the supply of IRD was overwhelmed by meltwater-derived sediment. However, iceberg scouring of the inner shelf and Fosters Bugt support iceberg production during deglaciation and the low IRD content could alternatively reflect the influence of polar water of the EGC that prevented iceberg melt and debris release.

Radiocarbon dates from sediments directly overlying the meltwater-derived laminated mud facies indicate that ice had abandoned the inner shelf before $9100{ }^{14} \mathrm{C}$ years BP and the outer fjord before $7440{ }^{14} \mathrm{C}$ years BP (Fig. 14). The thin nature of sediment cover on the shelf indicates that ice abandoned the inner shelf and established ice-distal conditions rapidly, but the timing of this is unknown. Terrestrial geological data from Kejser Franz Joseph Fjord point to stabilization of the ice margin in Fosters Bugt at $10000{ }^{14} \mathrm{C}$ years BP (Hjort 1979, 1981; Funder 1989; Funder \& Hansen 1996; Funder et al. 1998) (Fig. 14). The shallow Fosters Bugt and Bontekoe $\varnothing$ would have formed natural pinning points, thereby facilitating stabilization of the retreating ice margin during the Younger Dryas. Marine geological evidence in the form of moraines and ice-proximal sediment depocentres, such as that associated with the Milne Land stadial ice front in Scoresby Sund (e.g. Dowdeswell et al. 1994b), are absent. This may reflect Holocene iceberg scouring which has destroyed a significant proportion of the marine record in Fosters Bugt and on the inner shelf. Alternatively, the dominance of meltwater sediments in Fosters Bugt may reflect the continental retreat of the ice sheet margin from a position immediately east of Bontekoe $\varnothing$ after $10000{ }^{14} \mathrm{C}$ years BP.
There is no chronological data on deglaciation and the rate of glacier retreat from the middle fjord, but evidence from other East Greenland fjords suggests that glacier-ice had attained its present-day position by $6-7000$ ${ }^{14} \mathrm{C}$ years BP (Funder 1978, 1989) (Fig. 14). A drape of stratified glacimarine sediment directly overlying till or bedrock, coupled to the absence of ponded sediment depocentres suggests that glacier retreat through the outer fjord before $7440{ }^{14} \mathrm{C}$ years BP was fairly continuous. In contrast, glacier retreat through middle Kejser Franz Joseph Fjord was punctuated by stillstands in response to numerous pinning points. Glacier-ice stabilized in these topographically favourable positions, and fed sediment into iceproximal basins (prograding down-fjord) by subaqueous sediment gravity flow and suspension settling.

\section{Holocene ice-distal sedimentation in the middle-outer fjord and continental margin}

Ice-distal conditions became established in the middle-outer fjord during the Early Holocene. In this setting, a significant volume of sediment is transferred to the deep basins of the middleouter fjord by subaqueous debris flows and turbidity currents, producing interbedded, homogeneous sediment lobes and stratified sediment (Fig. 5; cf. Niessen \& Whittington 1997). Mass-flows are derived from sediments deposited along the margins of the middle-outer fjord by rock fall, deltas, alluvial fans and meltwater-processes. These sediments are prone to failure due to rapid sedimentation and the irregular and steep bathymetry of the fjord. Sediment-laden meltwater discharged into the middle-outer fjord and Fosters Bugt via a number of glacifluvial and fluvial systems (e.g. Badlandal and Paralleldal; Fig. 1c) and from glacier-fed turbid overflow plumes escaping the inner fjord, producing thick sequences of bioturbated and massive muds (PS2633, PS2632 and PS231). Sediment flux can reach $90 \mathrm{~cm} \mathrm{ka}^{-1}$, reflecting the narrow fjord physiography and proximity of meltwater sources, and the high volume of sediment transferred to this fjord by meltwater. The low amount of IRD indicates that meltwater sedimentation is dominant over iceberg rafting in this East Greenland fjord. Meltwater-derived muds are abundant close to fast-flowing outlet glaciers in fjords further to the south in East Greenland, in both Scoresby Sund and Kangerlussuaq Fjord (Smith \& Andrews 2000; Ó Cofaigh et al. 2001), as well as in fjords in the Canadian Arctic (Stewart 1991; Syvitski \& Hein 1991; Hein \& Syvitski 1992). Therefore, the 
relatively widespread occurrence of fine-grained lithofacies suggests that meltwater sedimentation can be relatively significant in polar glacimarine environments. Icebergs that do traverse the fjord system and Fosters Bugt actively scour the sea floor above $300 \mathrm{~m}$ water depth.

Meltwater escaping the middle-outer fjord and fjords further to the north in East Greenland also contribute significantly to the deposition of thick bioturbated mud facies in the inner shelf bathymetric deep. The high flux of sediment to the inner shelf (up to $117 \mathrm{~g} \mathrm{~cm}^{-2}$ $\mathrm{ka}^{-1}$ ) reflects the high volume of meltwaterderived sediment escaping the fjord systems, and is probably a function of the proximity of fluvial and glacifluvial systems that drain into the nearby outer fjord system. The middle-outer shelf is subject to intense erosion and winnowing by the East Greenland Current resulting in a lag of sandy gravelly diamicton (PS2630) and an apparent absence of finegrained sediment at the sea floor. The continental slope is comparatively sediment starved $\left(<4 \mathrm{~cm} \mathrm{ka}^{-1}\right)$ where hemipelagic sedimentation produces mud facies.

\section{Conclusions}

1. Geophysical and geological evidence indicates that during the LGM the Greenland Ice Sheet extended as far as the mid-continental shelf where its maximum grounded extent is marked by a prominent moraine.

2. Sediment flux to the continental slope during the LGM was high $\left(15-30 \mathrm{~cm} \mathrm{ka}^{-1}\right.$; $\left.16-65 \mathrm{~g} \mathrm{~cm}^{-2} \mathrm{ka}^{-1}\right)$ in response to ice-sheet advance onto the shelf. Sedimentation across the upper slope was characterized by the release of significant quantities of iceberg-rafted debris (diamicton facies) with subsequent downslope remobilization of this sediment by mass-flow (typically debris flow). On the middle-lower slope iceberg rafting and hemipelagic sedimentation (forming dropstone mud and sandy mud) were punctuated by deposition of diamicton and graded sand/gravel facies by mass flows derived from sediment failure on the upper slope. A downslope decrease in IRD reflects either the influence of the East Greenland Current confining icebergs to the upper slope, or progressive distance from the ice-sheet margin. Sediment gravity flows on the slope are likely to have fed into the East Greenland channel system, contributing to its formation.

3. Deglaciation commenced after 15300 ${ }^{14} \mathrm{C}$ years $\mathrm{BP}$ as indicated by $\delta^{18} \mathrm{O}$ isotope minima. Ice had abandoned the middle-shelf moraine before $13000{ }^{14} \mathrm{C}$ years BP. The presence of iceberg-rafted diamicton on the middle-outer shelf supports ice-mass loss through calving after 13000 years BP.

4. Iceberg rafting and deposition across the slope ceased during deglaciation reflecting increasingly ice-distal conditions and, possibly, confinement of icebergs to the shelf by the EGC. Fine-grained deposition by downslope currents dominated slope sedimentation at 15300 and $13000{ }^{14} \mathrm{C}$ years $\mathrm{BP}$, and may have been linked to an increase in brine rejection on the shelf.

5. Ice abandoned the inner shelf before 9100 ${ }^{14} \mathrm{C}$ years BP and stabilized in Fosters Bugt at $10000{ }^{14} \mathrm{C}$ years BP. The outer fjord was deglaciated before $7440{ }^{14} \mathrm{C}$ years BP. Sedimentologically, deglaciation is marked by an upward stratigraphic transition from acoustically opaque till or bedrock to laminated mud and bioturbated mud representing increasingly ice-distal conditions. Distinct $\delta^{18} \mathrm{O}$ isotope minima on the inner shelf indicate major meltwater production during deglaciation. Ice retreat through the middle-outer fjord was punctuated by topographically-controlled stillstands and ice-proximal sedimentation within the mid-fjord basin.

6. Holocene sediments on the middle-outer continental shelf are winnowed and eroded by the EGC, and the shelf is iceberg scoured. Sediment gravity flows transfer sediment to the deep basins of the Holocene ice-distal middle-outer fjord, producing interbedded acoustically transparent sediment lobes and stratified sediment. Sediment-laden meltwaters transfer high volumes of sediment at high fluxes (up to $111 \mathrm{~cm} \mathrm{ka}^{-1}$ and $117 \mathrm{~g} \mathrm{~cm}^{-2} \mathrm{ka}^{-1}$ ) to the outer fjord, Fosters Bugt and inner shelf, and produce thick sequences of bioturbated and massive mud. Meltwater sedimentation overwhelms iceberg rafting in this East Greenland fjord and shelf system. The relatively widespread occurrence of fine-grained lithofacies in East Greenland fjords suggests that meltwater sedimentation can be significant in polar glacimarine environments.

We thank the officers and crew of RV Polarstern during ARK X cruise in 1994, the shipboard scientific and technical party for assistance, and the technical support at AWI Bremerhaven and University of Wales, Aberystwyth. We are grateful to C. J. Pudsey (British Antarctic Survey) for the review of an earlier version of the manuscript. We also thank S. I. Nam and C. Vogt for discussions on the work. Data are available through the information system PANGAEA (http://www.pangaea.de). We thank Juergen Mienert and Antoon Kuijpers for formal reviews of the manuscript, and Colm Ó Cofaigh for scientific editing. 


\section{References}

Andersen, E. S., Dokken, T. M., Elverhøi, A., Solheim, A. \& Fossen, I. 1996. Late Quaternary sedimentation and glacial history of the western Svalbard continental margin. Marine Geology, 133, 123-156.

Andrews, J. T., Milliman, J. D., Jennings, A. E., RYNES, N. \& DWYER, J. 1994. Sediment thicknesses and Holocene glacial marine sedimentation rates in three East Greenland fjords (c. $\left.68^{\circ} \mathrm{N}\right)$. The Journal of Geology, 102, 669-683.

Andrews, J. T., Jennings, A. E., CoOPER, T., Williams, K. M. \& Mienert, J. 1996. Late Quaternary sedimentation along a fjord to shelf (trough) transect, East Greenland (c. 68 N). In: ANDREws, J. T., Austin, W. E. N., Bergsten, H. \& Jennings, A. E. (eds) Late Quaternary palaeoceanography of the North Atlantic margins. Geological Society, London, Special Publication, 111, 153-166.

Bouma, A. H. 1962. Sedimentology of flysch deposits. A graphic approach to facies interpretation. Elsevier, pp168.

Chappell, J. \& Shackleton, N. J. 1986. Oxygen isotopes and sea level. Nature, 324, 137-140.

Cowan, E. A. \& Powell, R. D. 1990. Suspended sediment transport and deposition of cyclically interlaminated sediment in a temperate glacial fjord, Alaska, U.S.A. In: Dowdeswell. J. A. \& SCOURSE, J. D. (eds) Glacimarine environments: Processes and sediments. Geological Society, London, Special Publication, 53, 75-89.

Cowan, E. A., Cai, J., Powell, R. D., Clark, J. D. \& PItcher, J. N. 1997. Temperate glacimarine varves: An example from Disenchantment Bay, Southern Alaska. Journal of Sedimentary Research, 67, 536-549.

Cowan, E. A., Seramur, K. C., Cai, J. \& Powell, R. D. 1999. Cyclic sedimentation produced by fluctuations in meltwater discharge, tides and marine productivity in an Alaskan fjord. Sedimentology, 46, 1109-1126.

Cremer, H., Wagner, B., Melles, M. \& Hubberten, H. W. 2001. The postglacial environmental development of Raffles $S \varnothing$, East Greenland. Journal of Paleolimnology, 26, 67-87.

DAMUTH, J. E. 1978. Echo character of the NorwegianGreenland Sea: relationship to Quaternary sedimentation. Marine Geology, 28, 1-36.

Dowdeswell, J. A., Villinger, H., Whittington, R. J. \& MARIEnfeld, P. 1993. Iceberg scouring in Scoresby Sund and on the East Greenland continental shelf. Marine Geology, 111, 37-53.

Dowdeswell, J. A., WhitTington, R. J. \& MARIENFELD, P. 1994a. Origin of massive diamicton facies by iceberg rafting and scouring, Scoresby Sund, East Greenland. Sedimentology, 41, 21-35.

Dowdeswell, J. A., UenZelmann-Neben, G., Whittington, R. J. \& MARIENFELD, P.1994b. The Late Quaternary sedimentary record in Scoresby Sund, East Greenland. Boreas, 23, 294-310.

Dowdeswell, J. A., Kenyon, N. H., Elverhøi, A., Laberg, J. S., Hollender, F.-J., Mienert, J. \& SIEGERT, M. J. 1996. Large-scale sedimentation on the glacier-influenced polar North Atlantic margins: long-range side-scan sonar evidence. Geophysical Research Letters, 23, 3535-3538.

DowdesWell, J. A., WhitTington, R. J. \& VillingeR, H. $1997 a$. Iceberg scours: records from broad and narrow-beam acoustic systems. In: DAVIES, T. A., Bell, T., Cooper, A. K., Josenhans, H., Polyak, L., Solheim, A., Stoker, M. S. \& Stravers, J. A. (eds) Glaciated continental margins: An atlas of acoustic images, Chapman and Hall, London, 27-29.

Dowdeswell, J. A., Kenyon, N. H. \& Laberg, J. S. 1997b. The glacier-influenced Scoresby Sund Fan, East Greenland continental margin: evidence from GLORIA and $3.5 \mathrm{kHz}$ records. Marine Geology, 143, 207-221.

Dowdeswell, J. A., Elverhøi, A. \& Spielhagen, R. 1998. Glacimarine sedimentary processes and facies on the Polar North Atlantic margins. Quaternary Science Reviews, 17, 243-272.

Dowdeswell, J. A., Ó Cofaigh, C., Taylor, J., Kenyon, N. H. \& Mienert, J. 2002. On the architecture of high-latitude continental margins: the influence of ice sheet and sea ice processes In: Dowdeswell, J. A. \& Ó Cofaigh, C. (eds) Glacier-Influenced Sedimentation on HighLatitude Continental Margins. Geological Society, London, Special Publication, 203, 33-54.

Elverhøi, A. \& Solheim, A. 1983. The Barents Sea ice sheet - a sedimentological discussion. Polar Research, 1, 23-42.

Elverhøi, A., Lonne, O. \& Seland, R. 1983. Glacimarine sedimentation in a modern fjord environment. Polar Research, 1, 127-149.

Elverhøi, A., Andersen, E. S., Dokken, T. M., Hebbeln, D., Spielhagen, R., Svendsen, J. L., Sorflaten, M., Rornes, A., Hald, M. \& ForsBerg, C. F. 1995. The growth and decay of the Late Weichselian Ice Sheet in Western Svalbard and adjacent areas based on provenance studies of marine sediments. Quaternary Research, 44, 303-316.

Elverhøi, A., Dowdeswell, J. A., Funder, S., Mangerud, J. \& Stein, R. 1998. Glacial and oceanic history of the Polar North Atlantic Margins: an overview. Quaternary Science Reviews, 17, 1-10.

Eyles, N., Eyles, C. H. \& Miall, A. D. 1983. Lithofacies types and vertical profile models; an alternative approach to the description and environmental interpretation of glacial diamict and diamictite sequences. Sedimentology, 30, 393-410.

FOLK, R. L. \& WARD, W. C. 1957. Brazos river bar, a study in the significance of grain size parameters. Journal of Sedimentary Petrology, 27, 34-59.

FUNDER, S. 1978. Holocene stratigraphy and vegetation history in the Scoresby Sund area, East Greenland. Grønlands geologiske Undersogeise, Bulletin 129, pp 66.

FUNDER, S. 1989. Quaternary geology of the ice-free areas and adjacent shelves of Greenland. In: FulTon, R. J. (ed.) Quaternary geology of Canada and Greenland. Geological Survey of Canada, Geology of Canada, 1, 743-792. 
Funder, S. \& Hansen, L. 1996. The Greenland Ice Sheet - a model for its culmination and decay during and after the last glacial maximum. Bulletin of the Geological Society of Denmark, 42, 137-152.

Funder, S., Huort, C., Landvik, J. Y., NAM, S.-I., REEH, N. \& STEIN, R. 1998. History of a stable ice margin - East Greenland during the middle and upper Pleistocene. Quaternary Science Reviews, 17, 77-123.

Grant, J. A. \& Schreiber, R. 1990. Modern swath sounding and sub-bottom profiling technology for research applications: The Atlas Hydrosweep and Parasound system. Marine Geophysical Research, 12, 9-19.

Grobe, H. 1987. A simple method for the determination of ice rafted debris in sediment cores. Polarforschung, 57, 123-126.

Hald, M., Dokken, T. \& Hagen, S. 1996. Palaeoceanography of the European Arctic margin during the last deglaciation. In: ANDREws, J. T., Austin, W. E. N., Bergsten, H. \& Jennings, A. E. (eds) Late Quaternary palaeoceanography of the North Atlantic margins. Geological Society, London, Special Publications, 111, 275-288.

Hampton, M. A. 1972. The role of subaqueous debris flow in generating turbidity currents. Journal of Sedimentary Petrology, 42, 775-793.

Hebbeln, D., Henrich, R. \& Baumann, K.-H. 1998. Paleoceanography of the last interglacial/glacial cycle in the Polar North Atlantic. Quaternary Science Reviews, 17, 125-153.

Hein, F. A. \& Syvitski, J. P. M. 1992. Sedimentary environments and facies in an Arctic basin, Itirbilung Fiord, Baffin Island, Canada. Sedimentary Geology, 81, 17-45.

Hill, P. R. 1984. Sedimentary facies of the Nova Scotian upper and middle continental slope, offshore eastern Canada. Sedimentology, 31, 293-309.

HJoRT, C. 1973. A sea correction for East Greenland, Geologiska Forenungen i Stockholm Forhandlungar, 95, 132-134.

HJORT, C. 1979. Glaciation in northern East Greenland during the Late Weichselian and Early Flanderian. Boreas, 8, 281-296.

HJorT, C. 1981. A glacial chronology for northern East Greenland. Boreas, 10, 259-274.

HopkINS, T. S. 1991. The GIN Sea - A synthesis of its physical oceanography and literature reviews 1972-1985. Earth Science Reviews, 30, 175-318.

Hubberten, H. W. (ed.) 1995. The expedition ARKX/2 with RV "Polarstern" 1994. Berichte zur Polarforschung, 174, Alfred Wegener Institut, Bremerhaven, p186.

Johnsen, S. J., Clausen, H. B., Dansgaard, W., Gunderstrup, N. S., Hansson, M., JonsSON, P., STEFFEnSEN, J. P. \& SVEInbJøRnsDotTiR, A. E. 1992. A 'deep' ice core from East Greenland. Meddelelser om Grønland, Geoscience 29, 22 pp.

JonEs, G. A. \& KEIGWIN, L. D. 1988. Evidence from Fram Strait $\left(78^{\circ} \mathrm{N}\right)$ for early deglaciation. Nature, 336, 56-59.

King, E. L., Haflidason, H., Sejrup, H. P. \& Løvlie,
R. 1998. Glacigenic debris flows on the North Sea Trough Mouth Fan during ice-stream maxima. Marine Geology, 152, 217-246.

Kunn, G. \& Weber, M. E. 1993. Acoustic characterization of sediments by Parasound and $3.5 \mathrm{kHz}$ systems: related sedimentary processes on the southeastern Weddell Sea continental slope, Antarctica. Marine Geology, 113, 201-217.

LABERG, J. S. \& VORREN, T. O. 1995. Late Weichselian submarine debris flow deposits on the Bear Island Trough Mouth Fan. Marine Geology, 127, $45-72$.

LABERG, J. S. \& Vorren, T. O. 1996. The middle and late Pleistocene evolution of the Bear Island Trough Mouth Fan. Global and Planetary Change, 12, 309-330.

Mackiewicz, N. E., Powell, R. D., CARlson, P. R. \& MolniA, B. F. 1984. Interlaminated ice-proximal glacimarine sediments in Muir Inlet, Alaska. Marine Geology, 57, 113-147.

MACLEAN, B. 1997. Submarine lateral moraine in the South Central Region of Hudson Strait, Canada. In: Davies, T. A., Bell, T., CoOper, A. K., Josenhans, H., Polyak, L., Solheim, A., Stoker, M. S. \& STRAVERS, J. A. Glaciated continental margins: An atlas of acoustic images, Chapman and Hall, London, 86-87.

MARIENFELD, P. 1991. Holozäne sedimentationsentwicklung im Scoresby Sund, Ost-Grönland. Berichte zur Polarforschung, 96, Alfred Wegener Institut, Bremerhaven, $166 \mathrm{p}$.

MARIENFELD, P. 1992a. Postglacial sedimentary history of Scoresby Sund, East Greenland. Polarforschung, 60, 181-195.

MARIENFELD, P. 1992 $b$. Recent sedimentary processes in Scoresby Sund, East Greenland. Boreas, 21, 169-186.

Melles, M. \& Kunn, G. 1993. Sub-bottom profiling and sedimentological studies in the southern Weddell Sea, Antarctica: evidence for large-scale erosional/depositional processes. Deep-Sea Research, 40, 739-760.

Middleton, G. V. \& Hampton, M. A. 1976. Subaqueous sediment transport and deposition by sediment gravity flows. In: STANLEY, D. J. \& SWIFT, D. J. P. (eds) Marine sediment transport and environmental management. John Wiley, New York, 197-218.

Mienert, J., Andrews, J. T. \& Milliman, J. D. 1992. The East Greenland continental margin $\left(65^{\circ} \mathrm{N}\right)$ since the last deglaciation: changes in seafloor properties and ocean circulation. Marine Geology, 106, 217-238.

Mienert, J., Kenyon, N. H., Thiede, J. \& Hollender, F. J. 1993. Polar continental margins: studies off East Greenland. EOS, 74, 225, 234, 236.

Mienert, J., Hollender, F. J. \& Kenyon, N. H. 1995. GLORIA survey of the East Greenland margin: $70^{\circ} \mathrm{N}$ to $80^{\circ} \mathrm{N}$. In: Crane, K. \& Solmeim, A. (eds) Seafloor atlas of the northern Norwegian-Greenland Sea. Norsk Polarinstitut Meddeleler, 137, 150-151.

NAM, S.-I. 1996. Late Quaternary glacial history and palaeoceanographic reconstructions along the 
East Greenland continental margin: Evidence from high resolution records of stable isotopes and ice rafted debris. PhD thesis, University of Bremen, $158 \mathrm{p}$.

Nam, S.-I., Stein, R., Grobe, H. \& Hubberten, H.-W. 1995. Late Quaternary glacial/interglacial changes in sediment composition at the East Greenland continental margin and their palaeoceanographic implications. Marine Geology, 122, 243-262.

Niessen, F. \& Whittington, R. J. 1997. Typical sections along a transect of a fjord in East Greenland. In: Davies, T. A., Bell, T., CoOper, A. K., Josenhans, H., Polyak, L., Solheim, A., Stoker, M. S. \& Stravers, J. A. (eds) Glaciated continental margins: An atlas of acoustic images. Chapman and Hall, London, 182-186.

Ó Cofaigh, C., Dowdeswell, J. A. \& Grobe, H. 2001 Holocene glacimarine sedimentation, inner Scoresby Sund, East Greenland: the influence of fast-flowing ice-sheet outlet glaciers. Marine Geology, 175, 103-129.

Ó Cofaigh, C., Taylor, J., Dowdeswell, J. A., Rosell-Melé, A., Kenyon, N. H., Evans, J. \& MienERT, J. 2002. Sediment reworking on highlatitude continental margins and its implications for palaeoceanographic studies: insights from the Norwegian-Greenland Sea. In: DowDEswell, J. A. \& Ó COFAIGH, C. (eds) Glacier-Influenced Sedimentation on High-Latitude Continental Margins. Geological Society, London, Special Publications, 203, 325-348.

PIPER, D. J. W. 1978. Turbidite muds and silts on deepsea fans and abyssal plains. In: StAnLey, D. J. \& Kelling, G. (eds) Sedimentation in Submarine Canyons, Fans and Trenches. 163-176.

Powell, R. D. 1983. Glacial-marine sedimentation processes and lithofacies of temperate tidewater glaciers, Glacier Bay, Alaska. In: MolNIA, B. F. (ed.) Glacial-marine sedimentation. Plenum, 185-232.

Powell, R. D. \& Molnia, B. F. 1989. Glacimarine sedimentary processes, facies and morphology of the south-southeast Alaska shelf and fjords. Marine Geology, 85, 359-390.

REEH, N. 1985. Greenland Ice-Sheet mass balance and sea-level change. In: Report DOE/EV/60235-1 Glaciers, ice sheets and sea level: Effect of a $\mathrm{CO}_{2}$ induced climatic change. U.S. Department of Energy, Washington DC, 155-171.

SARnTHein, M., JANSEN, E., ARnOld, M., DuPlessy, J.C., Erlenkeuser, H., Flatoy, A., Veum, T., Vogelsang, E. \& Weinelt, M. S. $1992 . \delta^{18}$ O timeslice reconstructions of meltwater anomalies at Termination I in the North Atlantic between 50 and 80 N. In: BARD, E. \& Broecker, W. S. (eds) The last deglaciation: Absolute and radiocarbon chronologies. NATO ASI Series, I2, SpringerVerlag Berlin Heidelberg, 184-200.

SHACKLETON, N. J. 1987. Oxygen isotopes, ice volume and sea level. Quaternary Science Reviews, 6, 183-190.

Smith, L. M. \& Andrews, J. T. 2000. Sediment characteristics in iceberg dominated fjords,
Kangerlussuaq region, East Greenland. Sedimentary Geology, 130, 11-25.

Solmeim, A., Faleide, J. I., Andersen, E. S., Elverhøi, A., Forsberg, C. F., VAnneste, K. \& Nenzelmann-Neben, G. 1998. Late Cenozoic seismic stratigraphy and glacial geological development of the East Greenland and Svalbard-Barents Sea continental margins. Quaternary Science Reviews, 17, 155-184.

Stein, R., Grobe, H., Hubberten, H.-W., MarienFELD, P. \& NAM, S.-I. 1993. Latest Pleistocene to Holocene changes in glaciomarine sedimentation in Scoresby Sund and along the East Greenland continental margin: Preliminary results. GeoMarine Letters, 13, 9-16.

Stein, R., Nam, S.-I., Schubert, C., Vogt, C., Fútterer, D. \& Heinemeier, J. 1994a. The last deglaciation event in the Eastern Central Arctic Ocean. Science, 264, 692-695.

Stein, R., Schubert, C., Vogt, C. \& Fütterer, D. $1994 b$. Stable isotope stratigraphy, sedimentation rates, and salinity changes in the latest Pleistocene to the Holocene eastern central Arctic Ocean. Marine Geology, 119, 333-355.

Stein, R., NAm, S.-I., Grobe, H. \& Hubberten, H.-W. 1996. Late Quaternary glacial history and short term ice rafted debris fluctuations along the East Greenland continental margin. In: ANDREws, J. T., Austin, W. E. N., Bergsten, H. \& Jennings, A. E. (eds) Late Quaternary palaeoceanography of the North Atlantic margins. Geological Society, London, Special Publication 111, 135-151.

STEWART, T. G. 1991. Glacial marine sedimentation from tidewater glaciers in the Canadian High Arctic. Geological Society of America, Special Paper 261, 95-104.

Stow, D. A. V. \& Shanmugam, G. 1980. Sequence of structures in fine-grained turbidites: comparison of recent deep-sea and ancient flysch sediments. Sedimentary Geology, 25, 23-42.

Svendsen, J. I., Mangerud, J., Elverhøi, A., Solheim, A. \& SCHUtTERHELM, R. T. E. 1992. The Late Weichselian glacial maximum on western Spitsbergen inferred from offshore sediment cores. Marine Geology, 104, 1-17.

SYVITSKI, J. 1989. On the deposition of sediment within glacier-influenced fjords: oceanographic controls. Marine Geology, 85, 301-329.

SyviTSKI, J. P. M. \& HeIn, F. J. 1991. Sedimentology of an Arctic Basin: Itirbilung Fiord, Baffin Island, Northwest Territories. Geological Survey of Canada, 91.

SYVITSKI, J. P. M., ANDREWS, J.T. \& DOWDESWELl, J. A. 1996a. Sediment deposition in an icebergdominated glacimarine environment, East Greenland: basin fill implications. Global and Planetary Change, 12, 251-270.

Syvitski, J. P. M., Lewis, C. F. M. \& PiPER, D. J. W. 1996b. Palaeoceanographic information derived from acoustic surveys of glaciated continental margins: examples from eastern Canada. In: Andrews, J. T., Austin, W. E. N., Bergsten, H. \& Jennings, A. E. (eds) Late Quaternary 
palaeoceanography of the North Atlantic margins, Geological Society, London, Special Publications, 111, 51-76.

Vogt. C., Matthiessen, J., Hubberten, H.-W. \& MonK, J. 1995. Water column investigations: Hydrography. In: Hubberten, H.-W. (ed) The expedition ARKTIS-X/2 of R.V. 'Polarstern' in 1994. Berichte zur Polarforschung, 174, 89-94.

Vorren, T. O., Laberg, J. S., Blaume, F., Dowdeswell, J. A., Kenyon, N. H., Mienert, J., Rumohr, J. \& Werner, F. 1998. The NorwegianGreenland Sea continental margins: morphology and Late Quaternary sedimentary processes and environment. Quaternary Science Reviews, 17, 273-302.

WadHAms, P. 1981. The ice cover in the Greenland and Norwegian Seas. Reviews of Geophysics and Space Physics, 19, 345-393.

Wagner, B., Melles, M., Hahne, J., Niessen, F. \& Hubberten, H. W. 2000. Holocene deglaciation and climate history on Geographical Society Island, East Greenland - evidence from lake sediments. Palaeogeography, Palaeoclimatology, Palaeoecology, 160, 45-68.

WALKER, R. G. 1992. Turbidites and submarine fans. In: Walker, R. G. \& James, N. P. (eds) Facies models: Response to sea level change. Geological Association of Canada, 239-263.

Yoon, S. H., Chough, S. K., Thiede, J. \& Werner, F. 1991. Late Pleistocene sedimentation on the Norwegian continental slope between $67^{\circ}$ and $71^{\circ}$ N. Marine Geology, 99, 187-207. 
